Article

\title{
Decision Support System for the Production of Miscanthus and Willow Briquettes
}

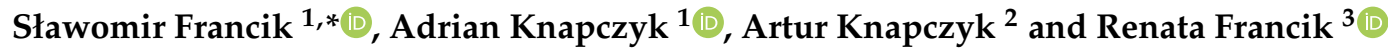 \\ 1 Department of Mechanical Engineering and Agrophysics, University of Agriculture in Krakow, Balicka 120, \\ 31-120 Kraków, Poland; adrian.knapczyk@urk.edu.pl \\ 2 Private Researcher, Kurow 26, 34-233 Kurow, Poland; artur.knapczyk@gmail.com \\ 3 Institute of Health, State Higher Vocational School, Staszica 1, 33-300 Nowy Sacz, Poland; \\ rfrancik@pwsz-ns.edu.pl \\ * Correspondence: slawomir.francik@urk.edu.pl; Tel.: +48-12-662-4641
}

Received: 31 January 2020; Accepted: 10 March 2020; Published: 15 March 2020

check for updates

\begin{abstract}
The biomass is regarded as a part of renewable energy sources (RES), which can satisfy energy demands. Biomass obtained from plantations is characterized by low bulk density, which increases transport and storage costs. Briquetting is a technology that relies on pressing biomass with the aim of obtaining a denser product (briquettes). In the production of solid biofuels, the technological as well as material variables significantly influence the densification process, and as a result influence the end quality of briquette. This process progresses differently for different materials. Therefore, the optimal selection of process' parameters is very difficult. It is necessary to use a decision support tool-decision support system (DSS). The purpose of the work was to develop a decision support system that would indicate the optimal parameters for conducting the process of producing Miscanthus and willow briquettes (pre-comminution, milling and briquetting), briquette parameters (durability and specific density) and total energy consumption based on process simulation. Artificial neural networks (ANNs) were used to describe the relationship between individual parameters of the briquette production process. DSS has the form of a web application and is opened from a web browser (it is possible to open it on various types of devices). The modular design allows the modification and expansion the application in the future.
\end{abstract}

Keywords: decision support system; briquettes production; willow; Miscanthus; artificial neural network; multilayer perceptron

\section{Introduction}

The usage of energy around the world is constantly rising. This is due to the increase in population and increasing demands of society [1,2]. The major part of energy today energy is obtained from burning fossil fuels. This is detrimental to the environment mainly because of greenhouse gas emissions [3]. The need for reducing the emission of greenhouse gases, and restricting the usage of fossil fuels with simultaneous increase in energy demand caused an increase in the amount of research regarding renewable energy sources (RES) $[4,5]$.

The biomass is regarded as a RES of high potential, which can satisfy energy demands of contemporary society both in developed and developing countries throughout the world [6-9]. The interest in biofuels created from different biomass types including agricultural energy waste and energy cultivations is growing $[10,11]$. The use of biomass to produce energy is around $50 \%$ of all RES in the world, and in Europe it is $70 \%$ [3]. Biomass can also be a raw material for the production of liquid and gaseous solid biofuels [11-13]. 
The growing global bioenergy market requires new biomass sources. Logging wood and wood biomass waste is insufficient. It is necessary to gradually replace it with agricultural biomass (energy plantations, aquatic plants and algae, agricultural waste, food processing waste and municipal solid waste $[8,14,15])$. The use of lignocellulosic biomass, e.g., Miscanthus, willow, poplar, acacia or paulownia as a source is particularly interesting $[5,11,16]$.

Biomass obtained from plantations is characterized by low bulk density, which increases transport and storage costs. For this reason, the shredded material is subjected to compaction using high pressure [8,17]. Briquetting is one of the basic technologies for thickening and converting biomass into solid biofuel-bio-briquettes intended for direct combustion $[8,10,18]$. Briquetting is a process that comprises several stages, such as initial shredding, milling and densifying. Sometimes drying the raw material or cooling the briquettes is required $[5,19,20]$.

Main qualitative parameters of briquettes are related to density, porosity and durability. Moisture content and compressive strength also influence the quality of briquette. These parameters are very significant from the viewpoint of logistic processes, combustion processes and so on [21,22]. Briquettes of bulk density above $1000 \mathrm{~kg} \cdot \mathrm{m}^{-3}$ are biofuels of high quality [23]. In the production of solid biofuels, the technological as well as material variables significantly influence the densification process, and as a result influence end quality of briquettes [24]. These factors can be divided into preproductive (material properties: particle size and moisture content), productive (impact of drying, storage or shredding on the properties of the material and the densification process) and post productive (storing, transport and trans-shipment conditions) $[19,23,24]$. The size of the particles and their distribution are included in the main factors determining the physical and mechanical properties of the briquette. Finer milling means higher density, hardness and durability, but also causes higher production costs [10]. Many researches were dedicated to describing and explaining the processes of biomass densification. The efficacy of the densification process stems from the quality of bonds between particles [10]. The process of densifying the fragmented biomass occurs under high pressure, which causes the contact area to increase, so adhesive forces lead to permanent connections between those particles [17]. The work delivered by pressure is partially converted into heat. During densification, the friction and shear in between the particles and between the particles and the briquetting machine, as well as the molecular adhesive forces cause the temperature of the briquette to increase [9].

Various types of biomass are used for the production of briquettes. The most widely and commonly used type for solid biofuel production is wood biomass (when considering commercial purposes, as it has high content of lignin-a natural binder). Others other than wood types may also be valid for such purposes [8]. Various species of Miscanthus and bamboo have great potential for bioenergy production due to high yield, high cellulose and hemicellulose content, high calorific value and low ash content [6,25]. Additionally, waste biomass from harvesting lines (poppy, oat, wheat and rice hulls) or corn waste can be used as raw materials for briquette production $[8,26,27]$.

As shown above, both the characteristics of the raw material and operational parameters are responsible for the quality of briquette. Therefore, in the production of solid biofuel (briquette), it is very important to understand the impact of these main factors on the properties of briquette. With this knowledge, product quality can be improved $[9,21]$.

Unfortunately, biomass as a raw material has vastly different properties. Therefore, there has not been a single, consistent mathematical description of the briquetting process so far. This process progresses differently for different materials. Therefore, the optimal selection of process' parameters (machine settings included in the production line) is very difficult. It is thus necessary to use decision support tools.

Operational research methods are classic decision support tools. However, due to the increasing complexity of decision-making problems and the growing possibilities of IT systems, in recent decades, a new type of tools supporting decision-makers has been developed: the so-called decision support systems (DSS). The definition formulated by Sprague and Carlson was [28,29]: "DSS comprises a class of information system that draws on transaction processing systems and interacts with the other parts 
of the overall information system to support the decision-making activities of managers and other knowledge workers in organizations". In recent years, there has been a rapid development of research on DSS. This is confirmed by the rapidly growing number of publications [29,30].

DSS is composed of three basic components, which are: the database management subsystem, the model base management subsystem and the dialog generation and management subsystem (user interface), which handles the interaction of the user with the system [28,30]. DSSs are used in many areas, e.g., IT, production engineering, transport, biosystem engineering and many more. In agricultural engineering, DSSs are used in pest management, crop production, biomass production, operational planning machine activities and pig products chains [29]. Decision support systems cover various parts of the supply chain. They are mostly used to deal with suppliers, optimize shipments, transport and production. The industries that most often use DSSs in the supply chain are manufacturing (e.g., medicine and fertilizer production, etc.) and agriculture. DSSs in the supply chain are also used in automotive processes, computers, construction, e-commerce, fisheries, food, forestry, logistics, medicine and petroleum [31-33]. DSSs are used to supplement energy-related decision processes [34]. Decision support systems were also a research subject in the field of RES. For example, DSSs have been developed for:

- Evaluation of energy and economic benefits of power to gas/heat technologies [35].

- The renewable energy management (a small scale photovoltaic energy production) based on the existing geographic information systems [36].

- Achieving energy balance in a low-voltage microgrid with RES (photovoltaic panels and wind turbines) [37].

- Supplementing the selection of optimal sites for grid-connected photovoltaic power plants using an environmental DSS [38].

- Setting priorities regarding the selection of bioenergy home heating sources in Southern Europe (DSS uses MCDA—multicriteria decision analysis—-methods) [39].

One of the components of DSSs is a model. It is important that they describe as accurately as possible the processes on which a DSS is expected to provide the decision-maker with information on the best solutions. The desire to increase the possibility of developing accurate decision variants has resulted in the emergence of intelligent DSSs, in which methods of artificial intelligence are used. In order to find dependencies between individual parameters describing the briquette production process artificial neural networks (ANNs), which are one of the methods of artificial intelligence, can be used.

The term artificial neural network refers to a computational and machine learning technique [40-43]. One type of neural networks are multilayer perceptron neural networks (MLPs). An MLP consists of an input layer, a hidden layer (one or two) and an output layer. Each layer consists of neurons with a non-linear activation function, which are connected to each other [44-46]. ANNs are universal nonlinear approximators. Implementation of artificial neural networks for different research proved to be very efficient and accurate [20,40,43,44,47-52].

ANNs are widely employed to exploit the empirical knowledge. Particularly, ANNs are applied in modeling, classification and clustering tasks, prediction processes, decision-making processes and management of industrial production systems [53]. ANNs are used in various scientific fields including, for example, bioinformatics, biochemistry, medicine, meteorology, economic sciences, robotics, aquaculture, food security and climatology. ANNs are also used in agriculture, agrophysics or agricultural engineering [20,40,44,47-49,51,54]. For example, an ANN was used to model paper production. An ANN was implemented to predict the fibers' length [53]. ANNs are also employed to control and predict variables in drying processes (a tomato drying model, tobacco and willow woodchips drying processes) [20,55]. Many applications of ANNs involve forecasting and prediction in agriculture. The ANNs with MLP topology to forecast winter rapeseed yields and winter wheat yield were developed $[46,56]$. The neural model forecasting temperature changes inside the heated foil tunnel enables the optimization of decisions regarding the control of heating system. Consequently, 
this allows one to lower the energy usage needed to ensure optimal internal climate in heated foil tunnel [44]. The ANN model can be also a part of a more complex DSS designated for internal climate management.

Some authors propose artificial neural networks (ANNs) for energy demand prediction and optimization (energy demand in smart grid; heating, ventilation and air conditioning energy savings in office buildings) [34]. Many ANN applications are related to renewable energy sources (different uses of ANN models for better energy production predictions). Research addresses for example the creation and use of ANNs to forecast solar radiation (the main problem for the best use of photovoltaic systems) and wind power forecasting [41,45,57-59]. ANNs are applied for forecasting building energy usage and demand [42]. The diversification of ANNs applications is vast, demonstrating the importance of this tool. ANNs are a powerful tool for making predictions based on a large number of interrelated experimental data $[20,44,47-50,52,55,60-63]$.

The aim of the work was to create a DSS, which could approximate optimal parameters for producing briquettes from Miscanthus and willow. Such parameters are durability and specific density (briquette parameters) and these associated with production processes (precomminution, milling and briquetting parameters).

\section{Materials and Methods}

As part of the work, a decision support system was designed, made and tested on a selected production line of plant biomass briquettes. The proposed decision support system is a continuation of a larger research cycle. The whole work consisted of 4 stages (Figure 1): I-conducting experimental tests, II-creating simulation models using ANN, III-performing simulation experiments and creating a database and IV-developing the inference module for the proposed DSS.

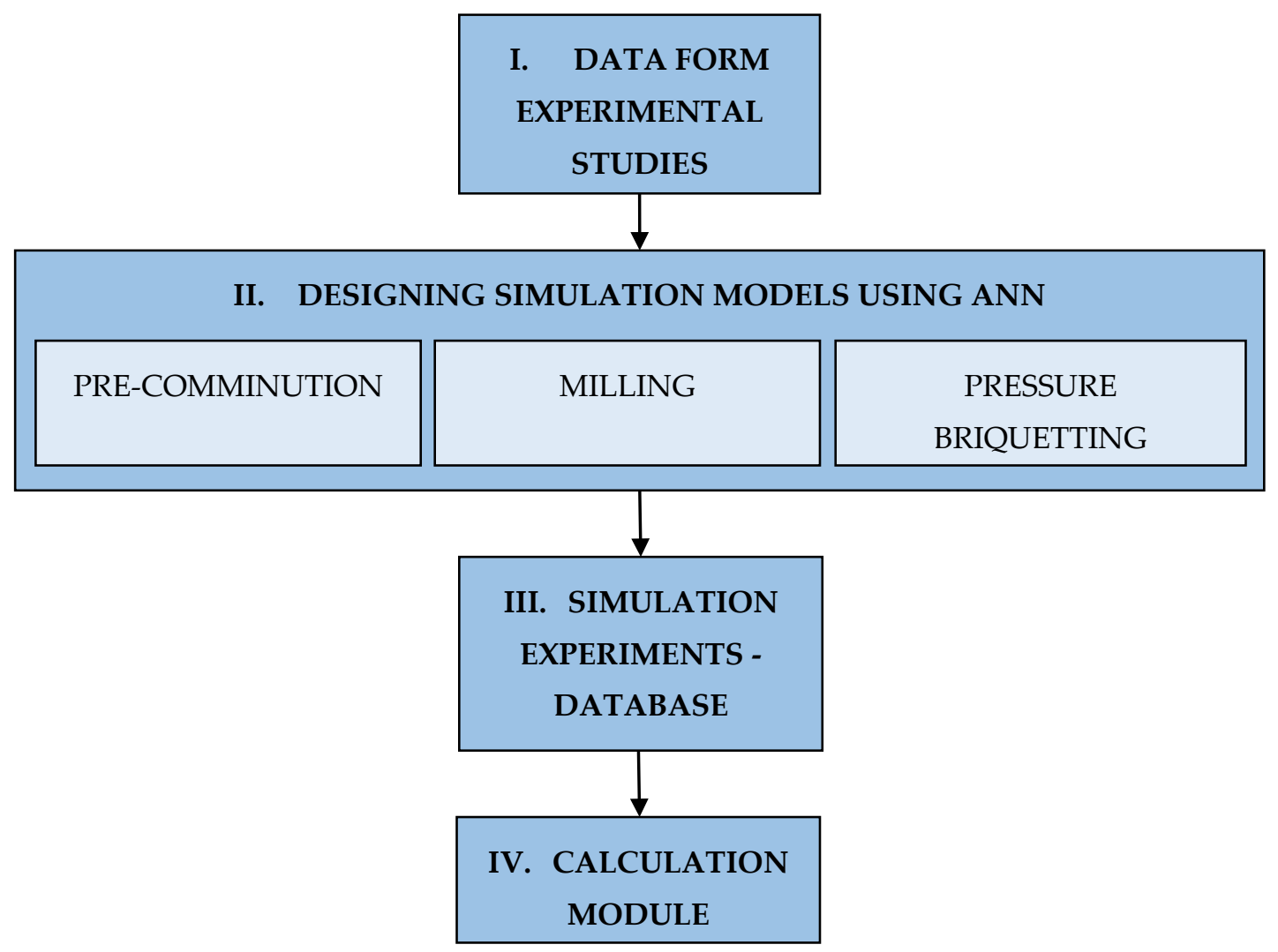

Figure 1. Stages of work. 


\subsection{Testing the Briquetting Process}

Stage I involved testing the briquetting process of the line located in the laboratory of the University of Agriculture in Krakow. The research material was obtained from the experimental plots of the Energy Plants Collection located at the Faculty of Production and Energy Engineering. The line diagram and parameters of the briquette production line are shown in the Figure 2. Briquettes obtained in the production process had a nominal diameter of $50 \mathrm{~mm}$ and a length of about $50 \mathrm{~mm}$.

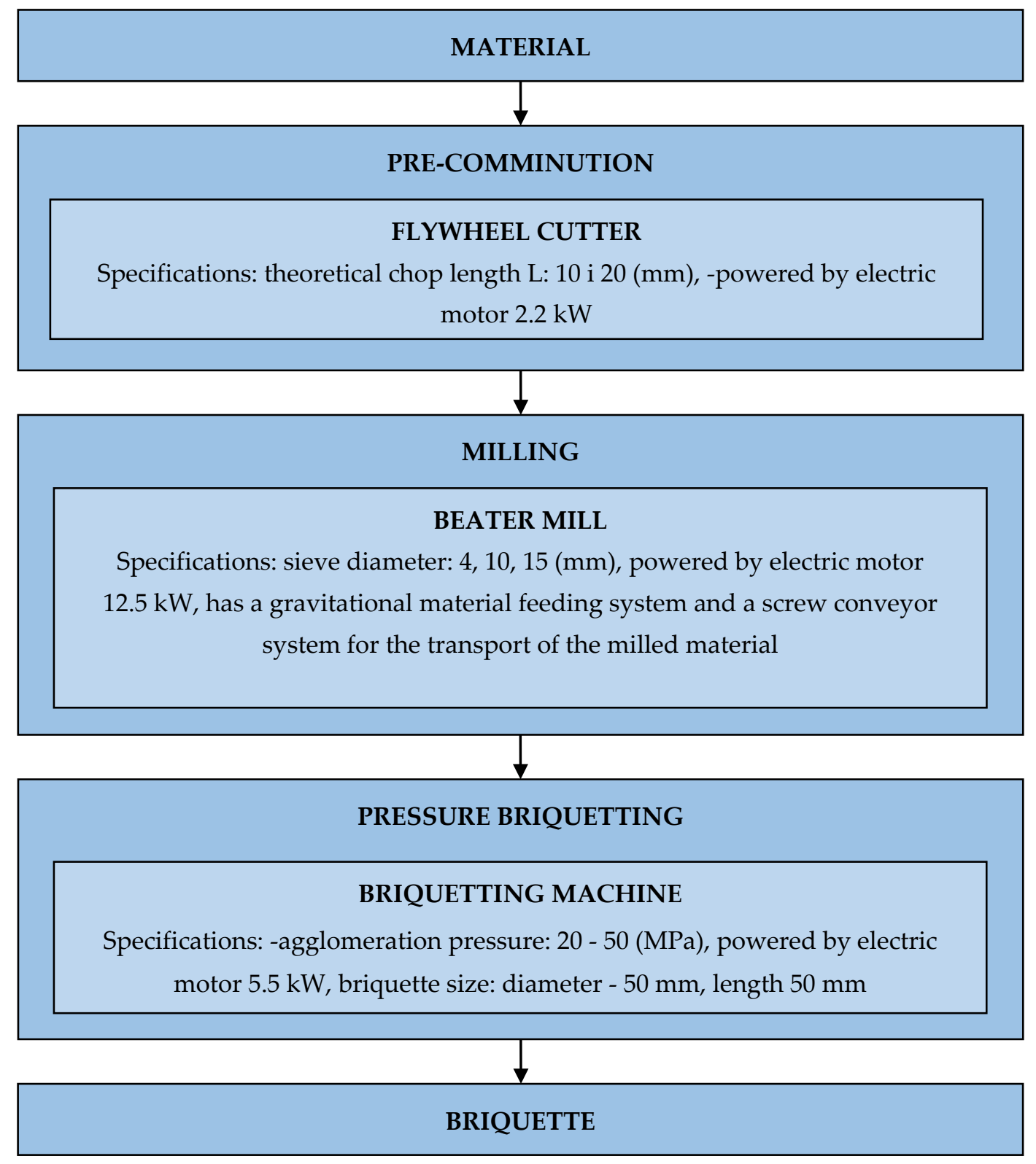

Figure 2. Diagram and parameters of the production line.

The resulting briquette quality was assessed according to the guidelines set in standards EN 15234-3:2012 (Solid biofuels-Fuel quality assurance-Part 3: Wood briquettes for non-industrial use). In accordance with the requirements in norm, a specific density of briquettes was set using a kit for determining the specific density-RADWAG - WPS 510/C/1. Next, the mechanical durability (DU) of the obtained briquettes was specified in accordance with the standard EN 15210-2:2011 (Solid 
biofuels—determination of mechanical durability of pellets and briquettes-Part 2: Briquettes). DU was calculated from the formula [64]:

$$
D U=\frac{m_{A}}{m_{B}} \cdot 100 \%
$$

where:

DU—mechanical durability of briquette, $\%$;

$\mathrm{m}_{\mathrm{A}}$ - mass of the sample after the test, $\mathrm{g}$;

$\mathrm{m}_{\mathrm{B}}-$ mass of the sample before the test, $\mathrm{g}$.

\subsection{Developing ANN Models}

Stage II consisted of developing ANN models for each stage of briquette production. Output parameters from individual stages were treated as input to the next.

It has been assumed that individual models will enable the following parameters to be determined:

1. For the precomminution process and the milling process:

- Energy consumption,

- Bulk density,

- Granulometric composition of the comminuted and the milled material (share of individual fractions).

2. For the briquetting process:

- Energy consumption,

- Specific density,

- Briquette durability.

Analysis of the production process and factors affecting the quality of the briquette allowed one to determine the inputs for individual models. For creating the models and the learning process of ANNs, the function "Automatic Designer" of Statistica was used. The back-propagation learning algorithm and then the conjugate gradient algorithm were used for each ANN. An ANN of the MLP type was chosen to create neural models.

The basic element of MLP is the so-called artificial neuron (Figure 3). The values of input variables and the threshold signal are fed to each neuron. These values are multiplied by the weights of individual inputs and then the products calculated in this way are added together. The resulting sum is transformed by a non-linear activation function resulting in an output signal at the neuron's output.

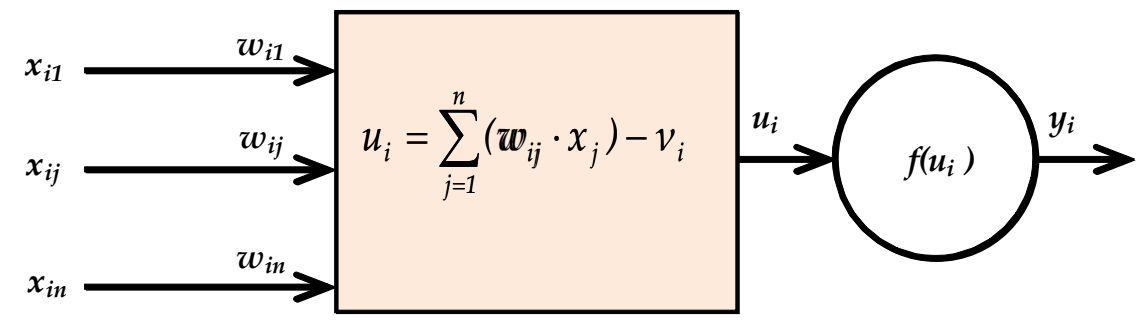

Figure 3. Diagram of an artificial neuron.

The structure of MLP networks is shown in Figure 4. These networks have a layered structure: input layer, hidden layers and output layer. Each layer has a different number of artificial neurons. Neurons of adjacent layers are connected to each other (no connections between neurons of the same layer). The value of the output from each neuron is passed to the inputs of all neurons of the next 
layer. In the case of output layer neurons, the values obtained are the result of calculations. There is a summary ANN response to the input values.

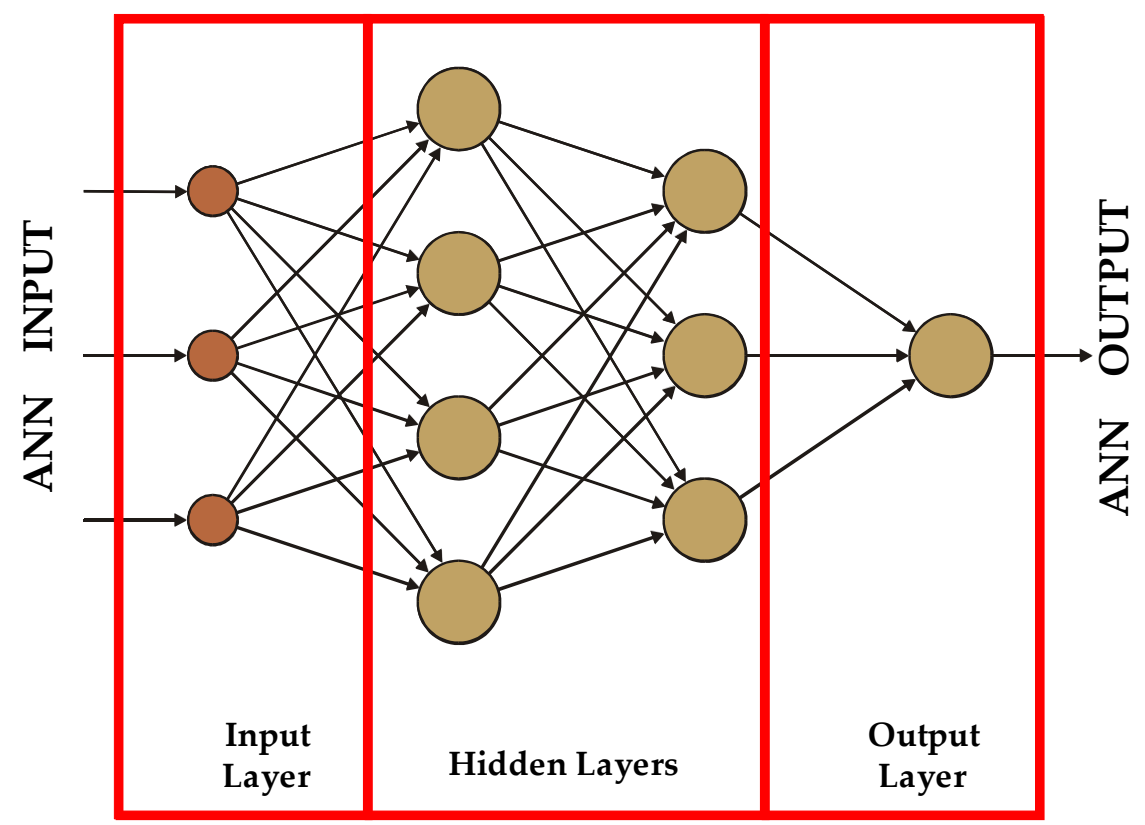

Figure 4. Diagram of the multilayer perceptron (MLP) type neural network.

ANNs are adapted to the modeled phenomenon during the learning process (weight changes for individual neurons occur). Gradient methods are used to teach MLP networks. Two such methods were used in the work: the back-propagation learning algorithm and then the conjugate gradient algorithm.

The values of the root mean-square error (RMSE) and mean absolute percentage error (MAPE) calculated for testing data set were the criterion of choice. RSME and MAPE are commonly used statistical errors to evaluate the model's performance [20,44-46,65].

The selection criteria were the root mean-square error (RMSE) and mean absolute percentage error (MAPE) calculated for the test data set. RSME and MAPE are commonly used statistical errors to assess model performance.

The RMSE and the MAPE were calculated from the following formulas:

$$
\begin{aligned}
& \text { RMSE }=\sqrt{\frac{1}{n} \cdot \sum_{i=1}^{n}\left(Y_{i}-Y_{A N N, i}\right)^{2}} \\
& M A P E=\frac{1}{n} \cdot\left|\frac{Y_{i}-Y_{A N N, i} \mid \cdot 100 \%}{Y_{i}}\right|
\end{aligned}
$$

where:

$n$-number of observations,

$Y_{i}$-values obtained during research,

$Y_{A N N, i}$-calculated by the ANN value.

Sensitivity analyses were performed for the created models in order to reject input variables that did not improve the accuracy of individual ANNs. The learning process has been repeated many times to obtain the best ANN. For each model, 100 neural networks of different architectures were tested, of which the best was selected.

\subsection{Performing Simulation Experiments and Creating A Database}

The following assumptions were made in the computer simulation process: 
1. The production of briquettes from Miscanthus and willow proceeds in three stages continuously - the material passes through subsequent devices without interoperational storage.

2. The moisture content decreases by $2 \%$ at every stage of production.

3. During the simulation, the humidity of the chipped material varied from $13 \%$ to $21 \%$.

4. Precomminution allows one to obtain chopped straw with a theoretical length of 10 and $20 \mathrm{~mm}$.

5. Milling is carried out in one step-only one sieve (sieve diameters: 15, 10 and $4 \mathrm{~mm}$ ).

6. Briquetting takes place at an adjustable pressure in the range of $20-56 \mathrm{MPa}$, every $2 \mathrm{MPa}$.

Based on computer simulations a database was created (Figure 5) for selected energy crops (Miscanthus, willow).

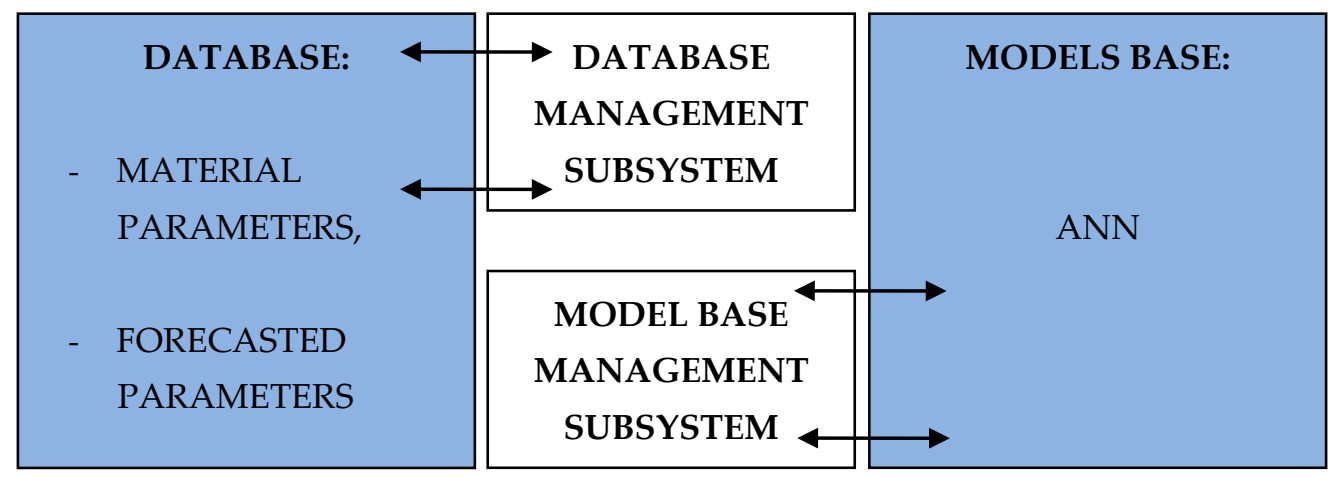

Figure 5. Organization chart of decision support system (DSS) elements (databases, database management subsystem, models databases and models database management subsystem).

\subsection{Developing the Inference Module for the Proposed DSS}

The final stage was the design and implement the inference module. This module was designed to calculate the optimal product and process parameters based on the total energy consumption. This module was an integral part of the computer program, which has also been designed and made as part of the work.

Assumptions for the designed application:

- Application in web technology,

- Responsive work mode,

- The ability to generate, modify and save reports,

- The ability to add more energy crops,

- Modular nature of the application,

- Expandable.

\section{Results}

In Figure 6 the essence of the DSS is shown. The ANN models used in the developed DSS are shown on Figures 7-11. Inputs and outputs of individual ANNs and connections between them are marked. 

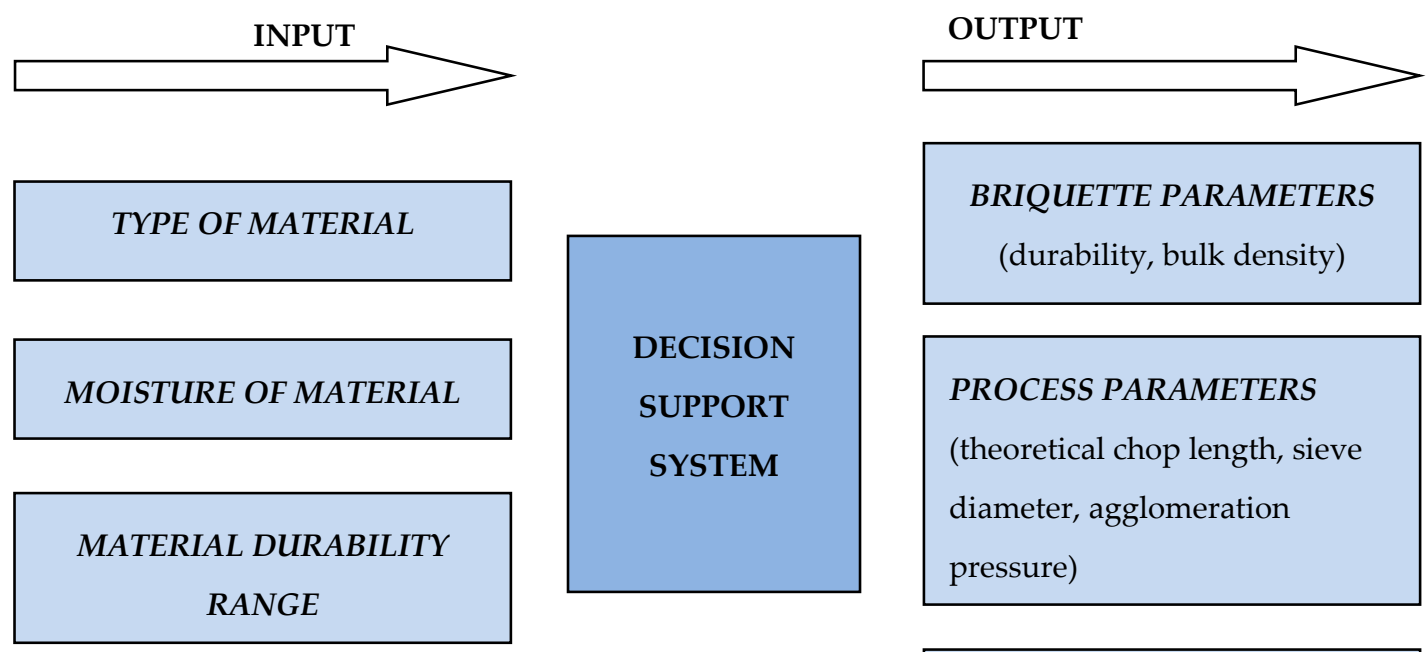

BRIQUETTE PARAMETERS

(durability, bulk density)

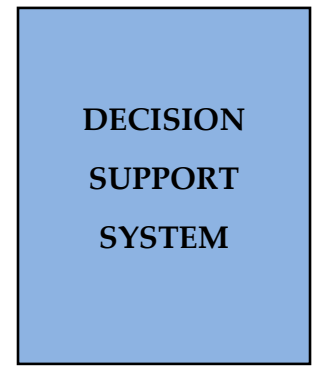

\section{PROCESS PARAMETERS}

(theoretical chop length, sieve diameter, agglomeration pressure)

TOTAL ENERGY CONSUMPTION

Figure 6. The essence of the DSS.

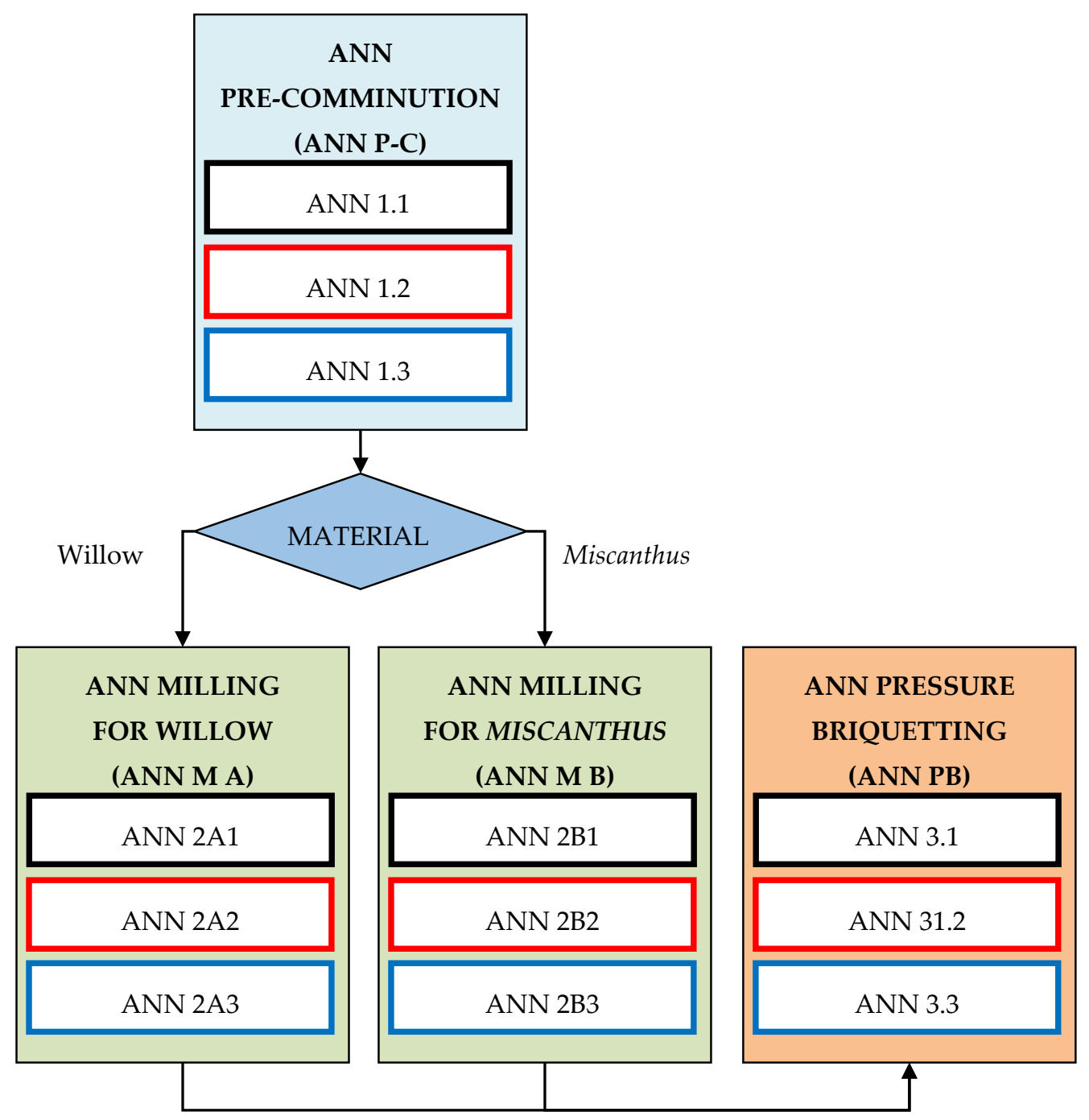

Figure 7. Models obtained for individual stages of the briquettes production process. 


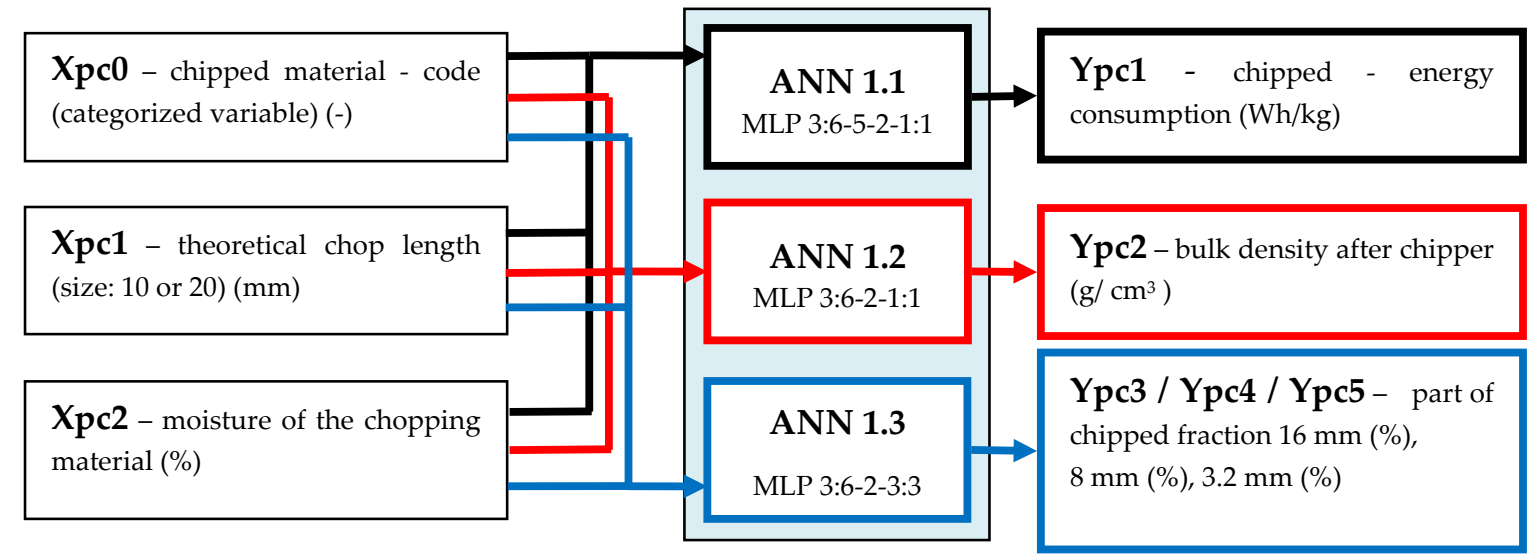

Figure 8. Inputs and outputs of individual artificial neural networks (ANNs) of the precomminution process.

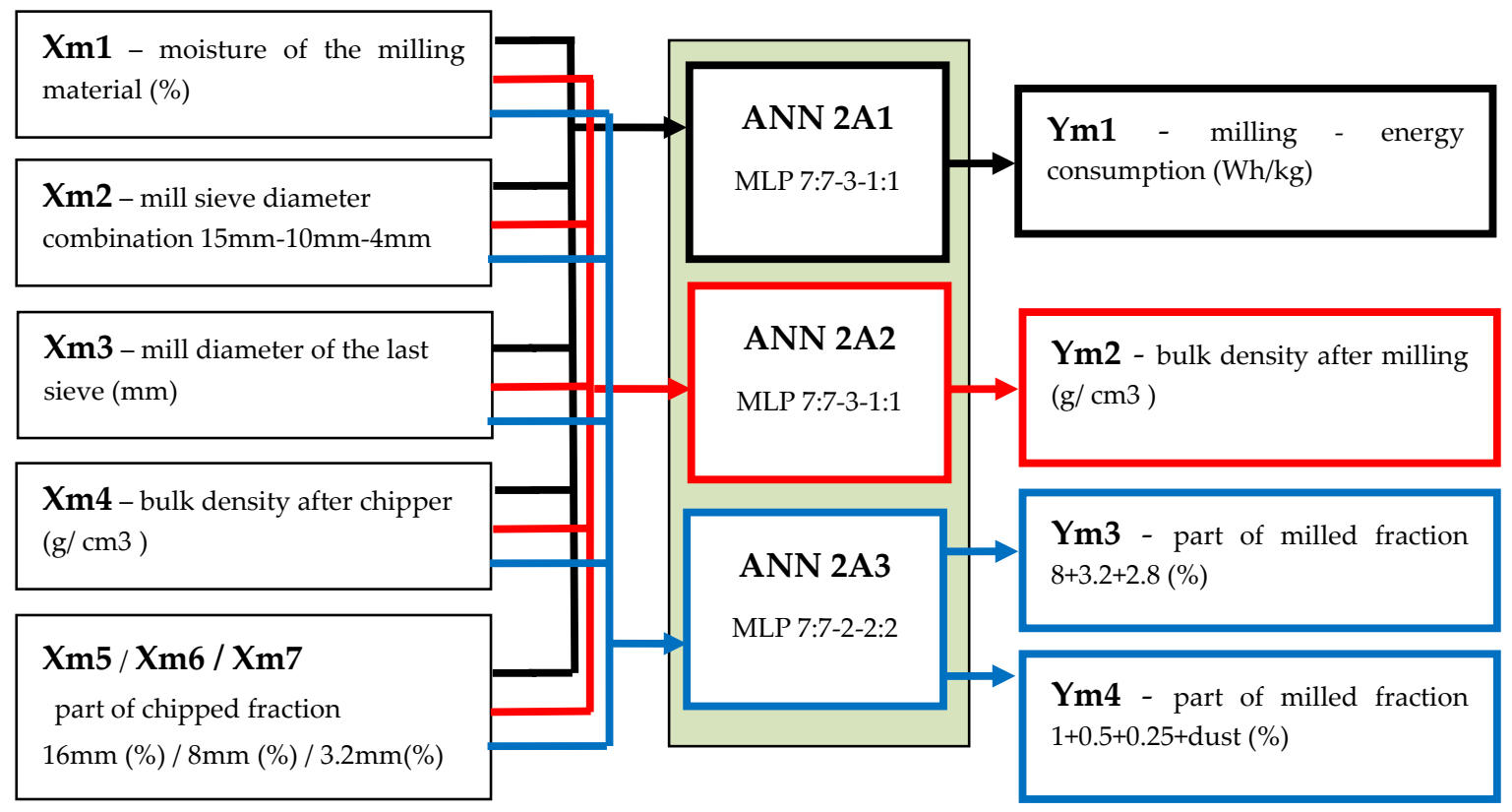

Figure 9. Inputs and outputs of individual ANNs of the milling process-willow. 


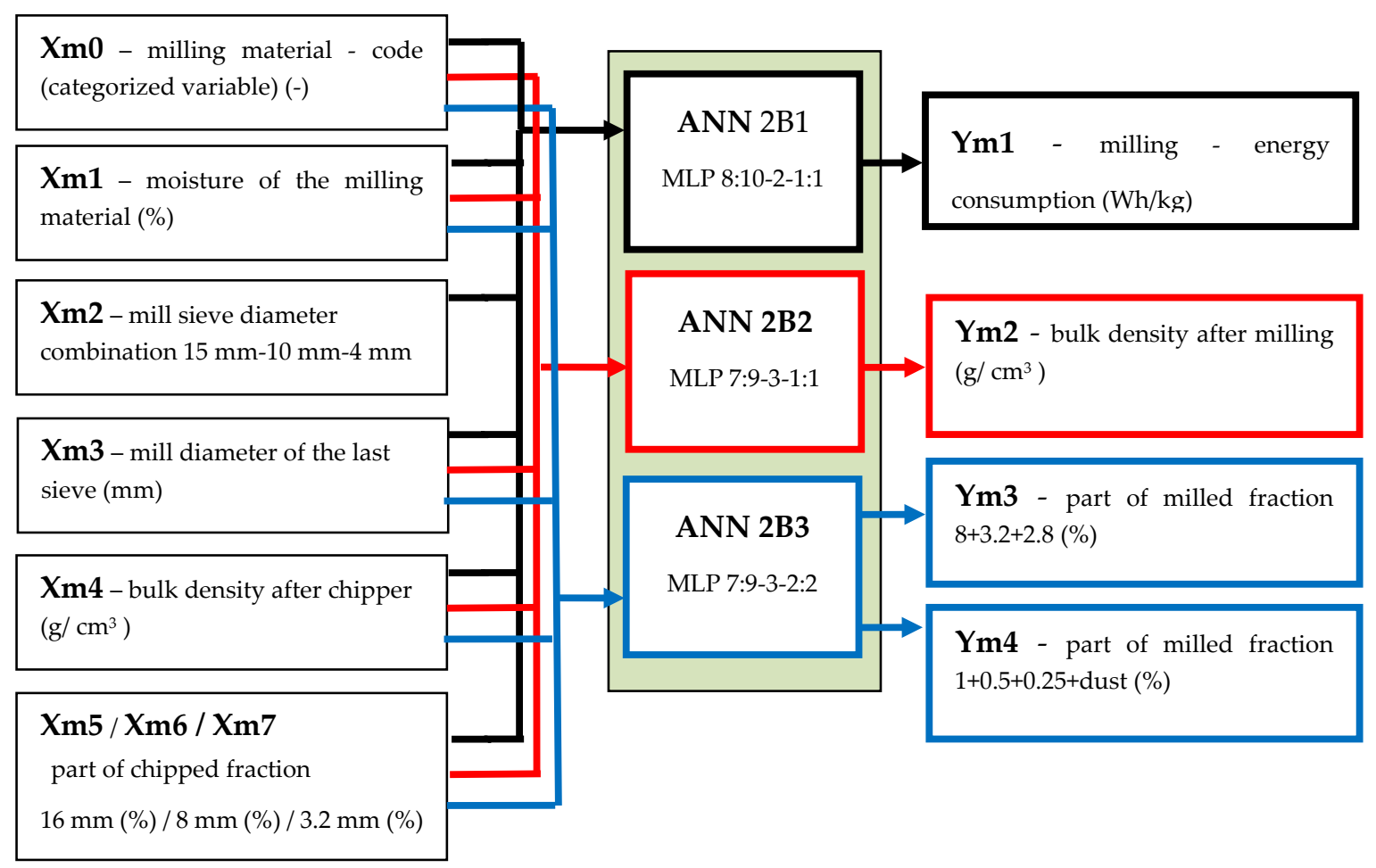

Figure 10. Inputs and outputs of individual ANNs of the milling process-Miscanthus.

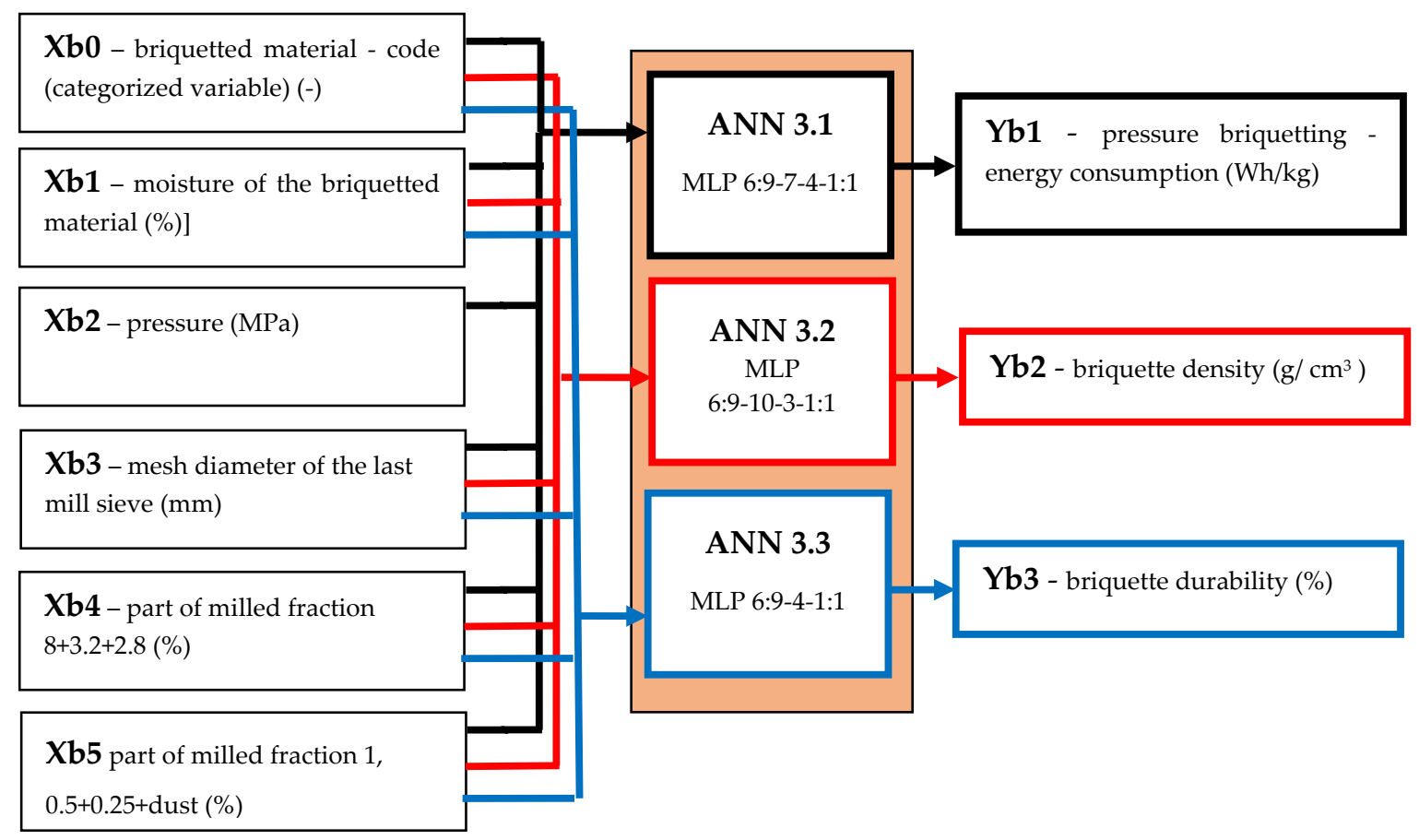

Figure 11. Inputs and outputs of individual ANNs of the briquetting process. 
Tables 1-3 present the RMSE and MAPE error values calculated for ANN models describing the precomminution, the milling and the briquetting processes. Figure 12 shows a comparison of parameter values describing the briquetting process obtained using ANNs with average values measured during experimental tests for a selected example for the diameter of the last mill sieve (diameter $=15 \mathrm{~mm}$ ).

Table 1. Root mean-square error (RMSE) and mean absolute percentage error (MAPE) error values calculated for ANNs describing the precomminution process.

\begin{tabular}{|c|c|c|c|c|c|c|}
\hline \multirow[b]{2}{*}{ ANN } & \multicolumn{2}{|c|}{ Energy Consumption } & \multicolumn{2}{|c|}{ Bulk Density } & \multicolumn{2}{|c|}{ Parts of Chipped Fractions } \\
\hline & $\begin{array}{c}\text { RMSE } \\
\text { (Wh/kg) }\end{array}$ & $\begin{array}{c}\text { MAPE } \\
(\%)\end{array}$ & $\begin{array}{l}\text { RMSE } \\
\left(\mathrm{g} / \mathrm{cm}^{3}\right)\end{array}$ & $\begin{array}{c}\text { MAPE } \\
(\%)\end{array}$ & $\begin{array}{c}\text { RMSE } \\
(\%)\end{array}$ & $\begin{array}{c}\text { MAPE } \\
(\%)\end{array}$ \\
\hline Willow & 0.17 & 10.27 & 0.000642 & 0.21 & 2.50 & 10.08 \\
\hline Miscanthus & 0.11 & 3.73 & 0.001187 & 1.28 & 1.72 & 8.40 \\
\hline
\end{tabular}

Table 2. RMSE and MAPE error values calculated for ANNs describing the milling process.

\begin{tabular}{ccccccc}
\hline & \multicolumn{2}{c}{ Energy Consumption } & \multicolumn{2}{c}{ Bulk Density } & \multicolumn{2}{c}{ Parts of Milled Fractions } \\
\hline \multirow{2}{*}{ ANN } & $\begin{array}{c}\text { RMSE } \\
\mathbf{( W h / k g )}\end{array}$ & $\begin{array}{c}\text { MAPE } \\
\mathbf{( \% )}\end{array}$ & $\begin{array}{c}\text { RMSE } \\
\mathbf{( g / \mathbf { c m } ^ { 3 } )}\end{array}$ & $\begin{array}{c}\text { MAPE } \\
\mathbf{( \% )}\end{array}$ & $\begin{array}{c}\text { RMSE } \\
\mathbf{( \% )}\end{array}$ & $\begin{array}{c}\text { MAPE } \\
\mathbf{( \% )}\end{array}$ \\
\hline Willow & 3.38 & 5.48 & 0.00212 & 1.31 & 2.79 & 5.90 \\
Miscanthus & 2.44 & 6.56 & 0.00027 & 0.24 & 1.30 & 3.79 \\
\hline
\end{tabular}

Table 3. RMSE and MAPE error values calculated for ANNs describing the briquetting process.

\begin{tabular}{ccccccc}
\hline & \multicolumn{2}{c}{ Energy Consumption } & \multicolumn{2}{c}{ Briquette Density } & \multicolumn{2}{c}{ Briquette Durability } \\
\hline \multirow{2}{*}{ ANN } & $\begin{array}{c}\text { RMSE } \\
\mathbf{( W h / k g )}\end{array}$ & $\begin{array}{c}\text { MAPE } \\
\mathbf{( \% )}\end{array}$ & $\begin{array}{c}\text { RMSE } \\
\mathbf{( g / \mathbf { c m } ^ { 3 } )}\end{array}$ & $\begin{array}{c}\text { MAPE } \\
\mathbf{( \% )}\end{array}$ & $\begin{array}{c}\text { RMSE } \\
\mathbf{( \% )}\end{array}$ & $\begin{array}{c}\text { MAPE } \\
\mathbf{( \% )}\end{array}$ \\
\hline Willow & 1.22 & 3.43 & 0.0174 & 1.76 & 1.42 & 1.31 \\
Miscanthus & 1.63 & 3.26 & 0.0156 & 1.43 & 1.02 & 0.91 \\
\hline
\end{tabular}

The detailed algorithm of the DSS inference module operation is presented in Figure 13.

The application has a web form and is opened from a web browser. The technologies used were the project in the Model-View-Controller (MVC) design pattern, Java programming language and elements of the SQL programming language. The following libraries were used: Spring MVC, Spring Web, Spring Security and Hibernate. The application has been scaled to one database server. Postgre SQL server version 9.4 was chosen. Coding was done using the NetBeans programming environment. 
(a)

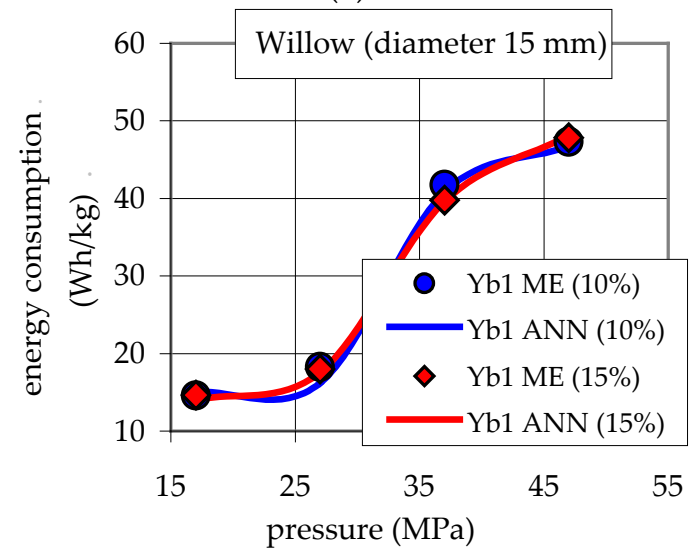

(b)

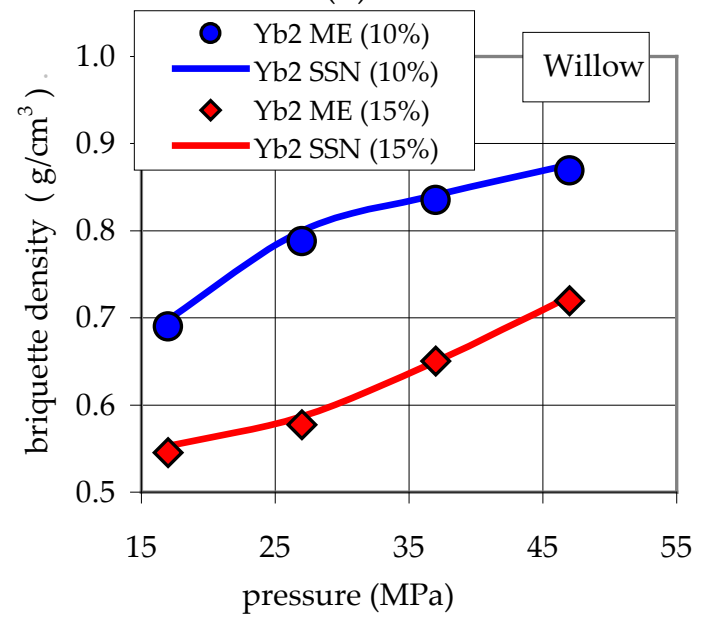

(c)

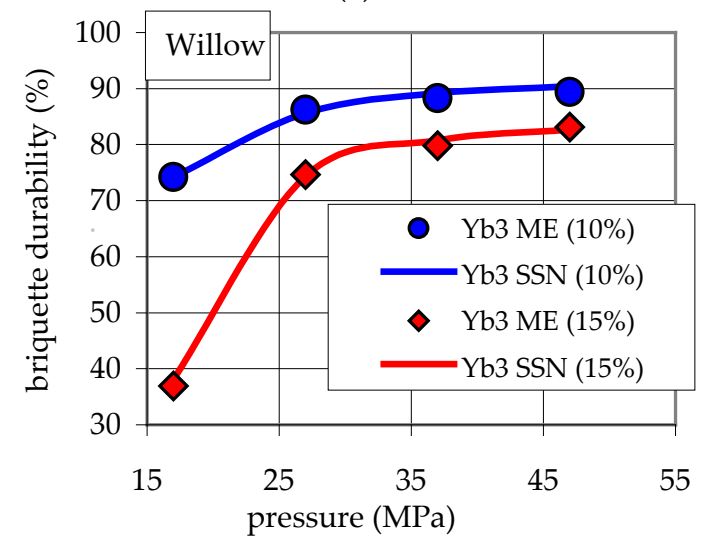

(d)

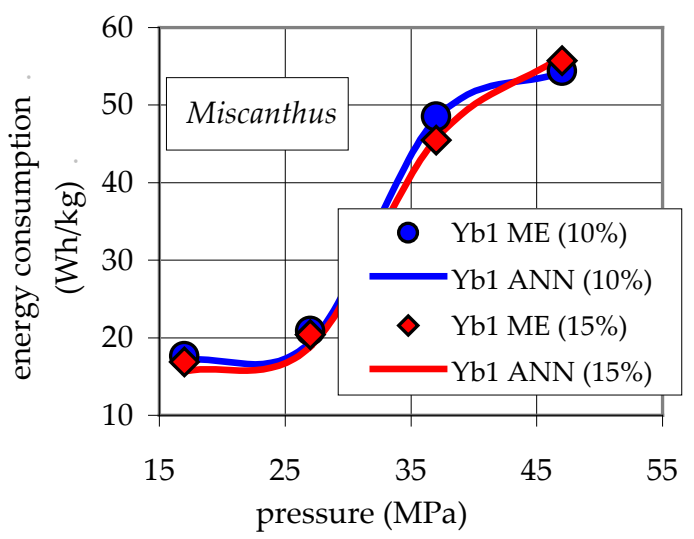

(e)

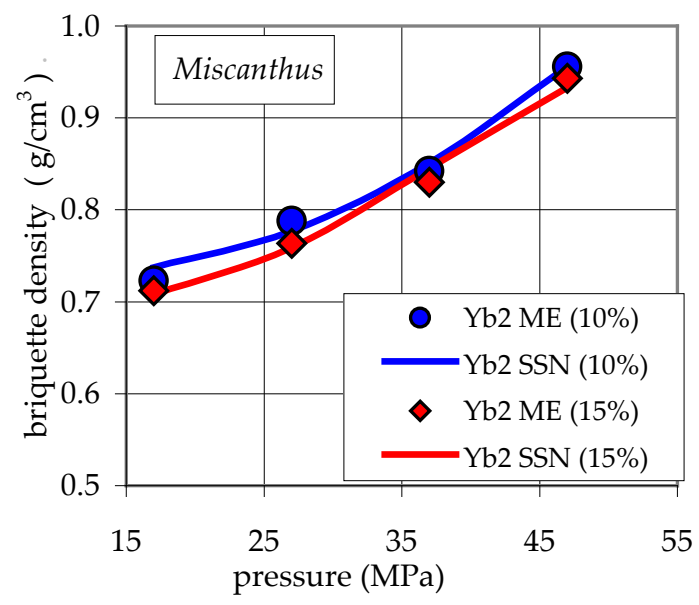

(f)

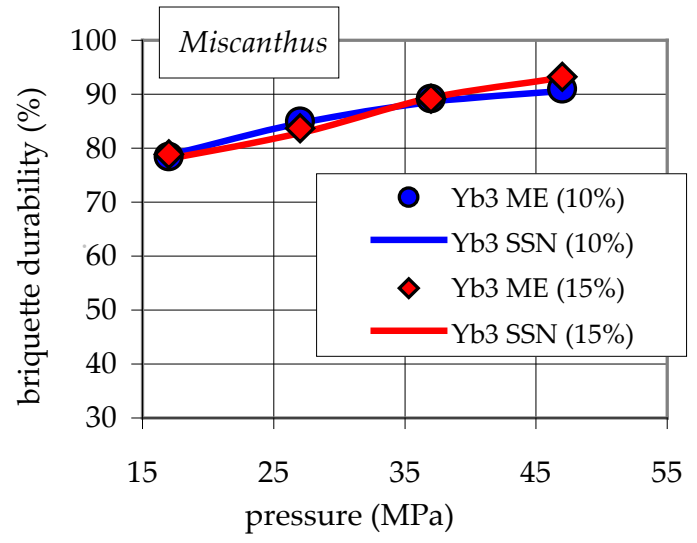

Figure 12. Comparison of parameter values describing the briquetting process obtained using ANNs with average values measured during experimental tests (for the diameter of the last mill sieve of $15 \mathrm{~mm}$ ): (a) energy consumption for Willow; (b) briquette density for Willow; (c) briquette durability for Willow; (d) energy consumption for Miscanthus; (e) briquette density for Miscanthus; (f) briquette durability for Miscanthus. 


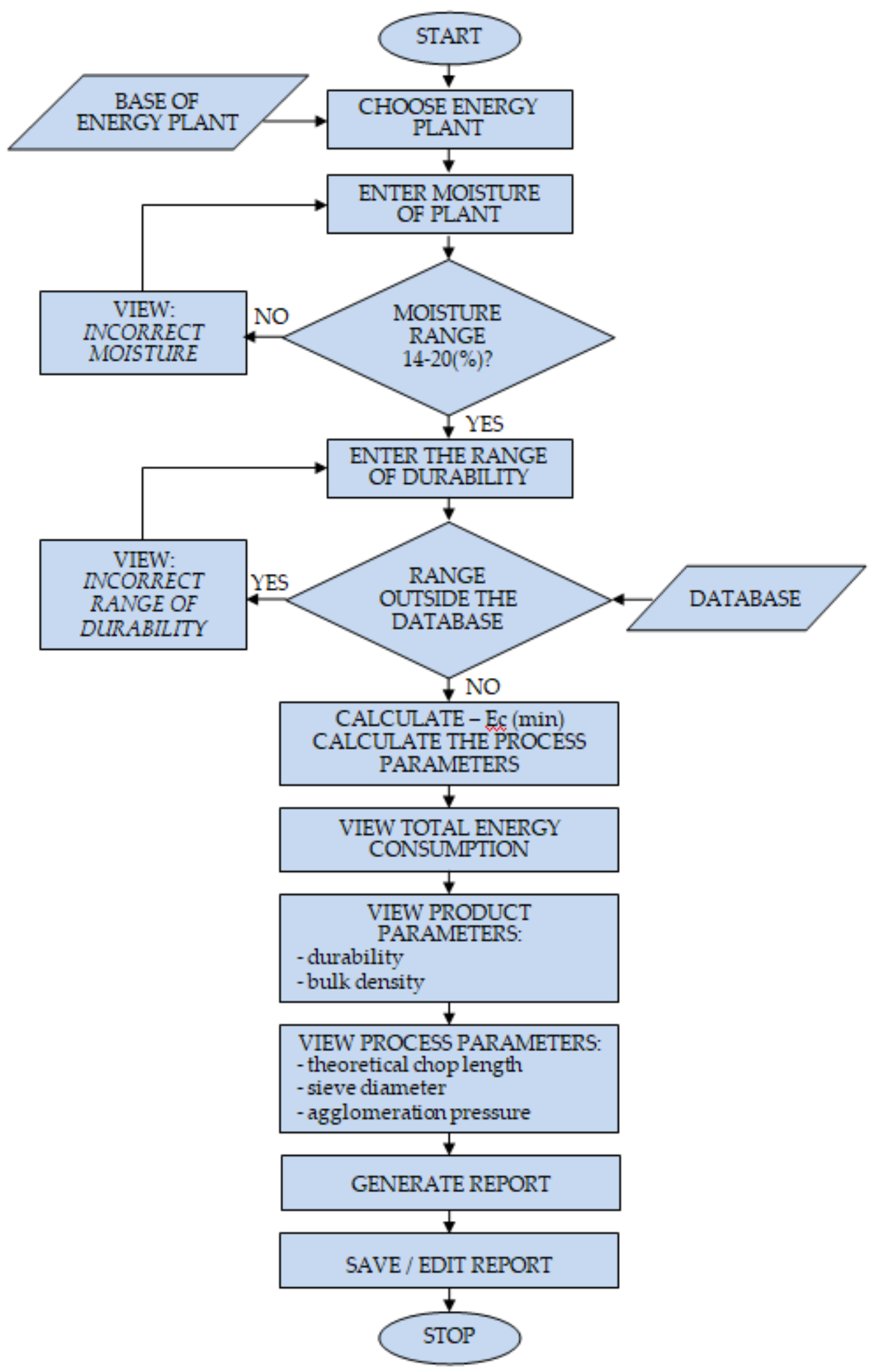

Figure 13. The algorithm of the inference module.

The system was developed using elements of graphical notation of the UML (unified modeling language). The program also meets the principles used in software engineering. Two sample schemes were selected, namely a use case diagram (Figure 14) and an implementation diagram (Figure 15). 


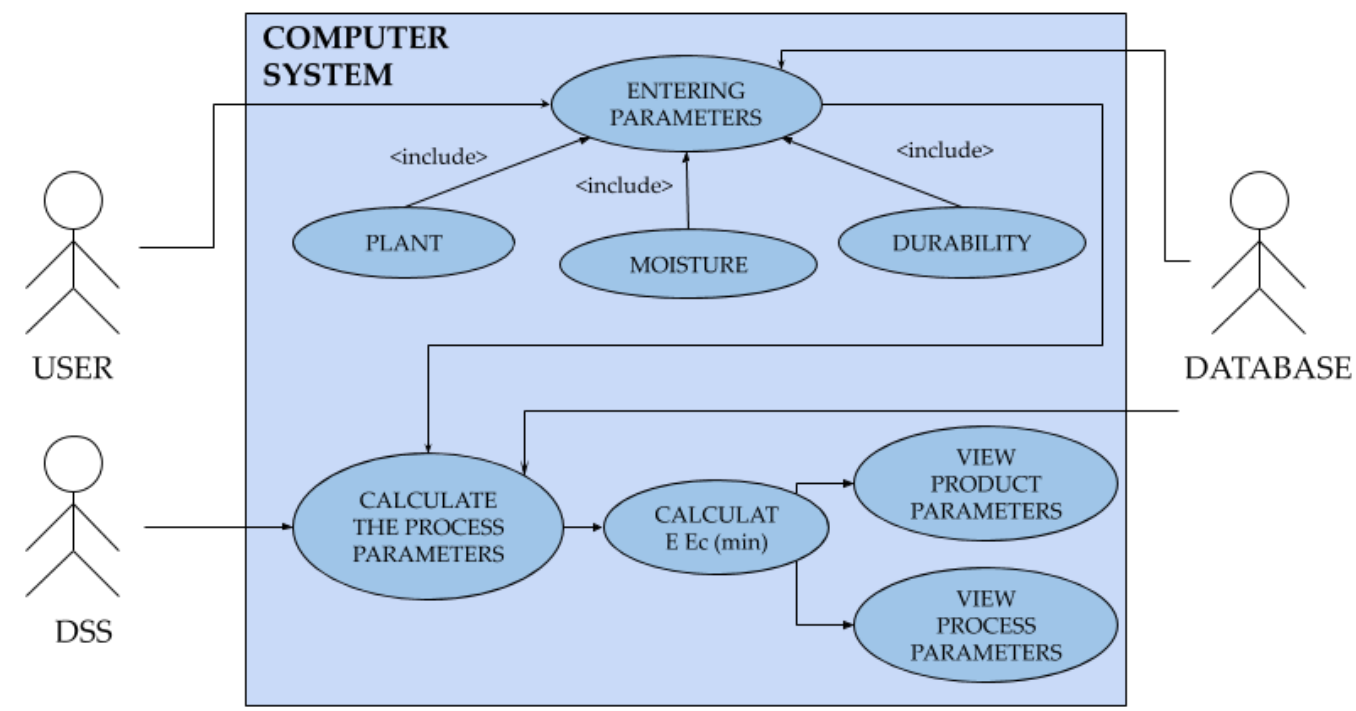

Description:

Designations used in accordance with UML notation:

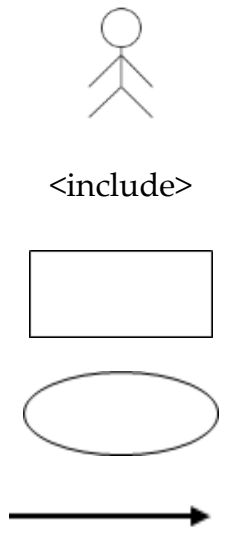

- Part of the system;

- Means that the selected parameters are selectable;

- System boundaries;

- Task and parameters;

- Information flow.

Figure 14. Use case diagram. 


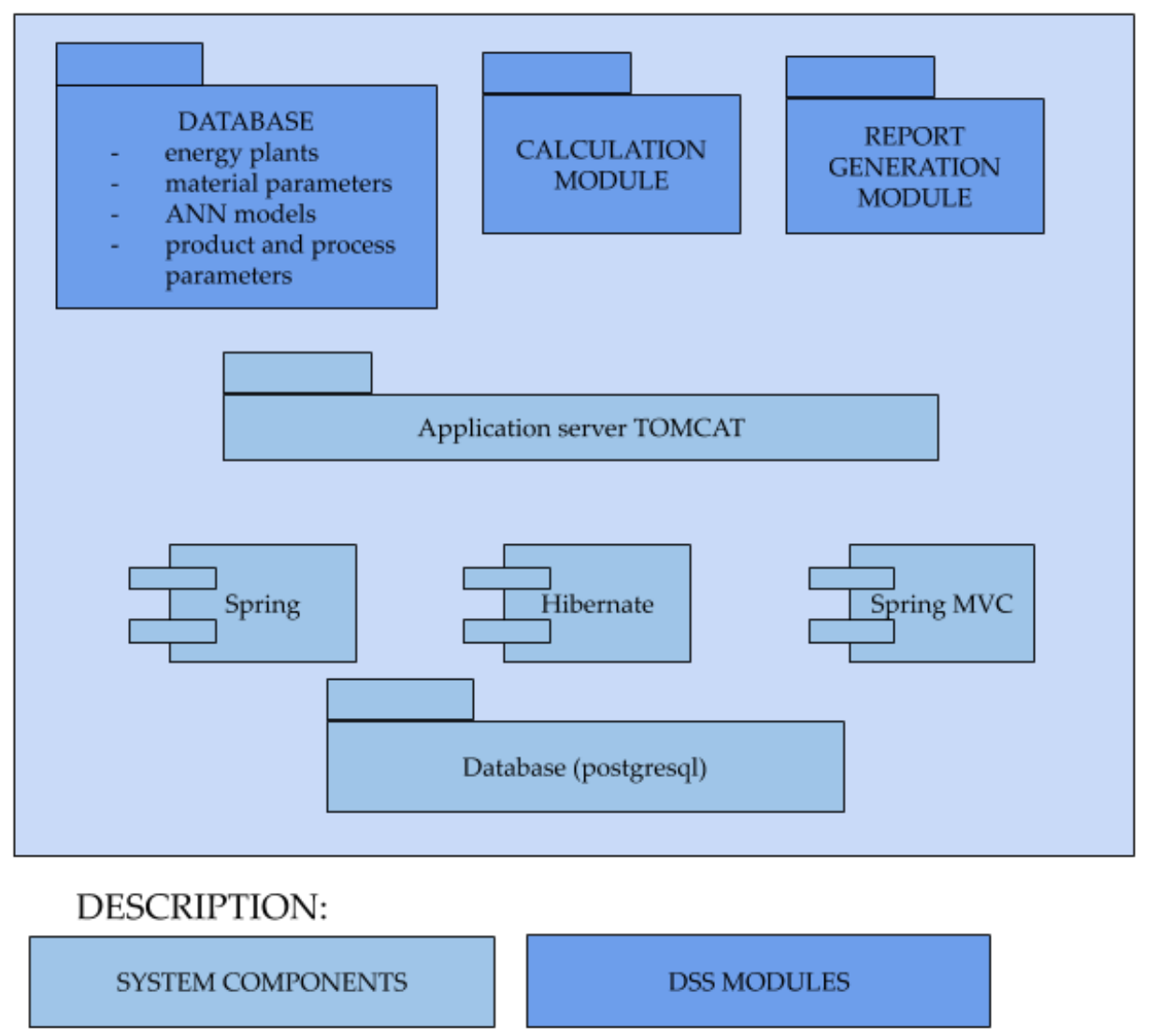

Figure 15. Implementation diagram.

\section{Discussion}

As part of this work, a DSS (Figure 6), which is designed to assist the user in the selection of process parameters for a given line producing briquettes from energy plants based on input parameters based on data from simulations has been designed and made.

The requirement for the proper operation of DSSs is the accuracy of models describing individual processes. ANNs models used in our DSS show high accuracy of calculations (independent models were developed to calculate particular output variables).

For the precomminution process (Table 1 ) the MAPE error values varied from $0.21 \%$ to $10.27 \%$. The lowest errors occurred for bulk density (MAPE $=0.21 \%$ and $1.28 \%$ ). The ANN model calculating the values of the parts of chipped fractions variable was the least accurate (MAPE $=10.08 \%$ for willow and MAPE $=8.40 \%$ for Miscanthus). For variables "energy consumption" and "parts of chipped fractions" ANNs were more accurate for Miscanthus. The ANN accuracy for bulk density is very high for both plants.

For the milling process (Table 2) the MAPE error values varied from $0.24 \%$ to $6.56 \%$. Additionally, in this case, the lowest errors occurred for bulk density (MAPE $=1.31 \%$ for willow and MAPE $=0.24 \%$ for Miscanthus). The error values for energy consumption and parts of milled fractions did not exceed a few percent and show the high accuracy of the models (MAPE $=5.48 \%$ and $5.90 \%$ for willow and MAPE $=6.45 \%$ and $3.79 \%$ for Miscanthus).

For the briquetting process (Table 3), the MAPE error values varied from $0.91 \%$ to $3.43 \%$. The highest error values occurred for energy consumption (MAPE $=3.43 \%$ for willow and MAPE $=3.26 \%$ for Miscanthus). For the other two output variables, these errors were much lower: MAPE $=1.76 \%$ and $1.43 \%$ for briquette density and MAPE $=1.31 \%$ and $0.91 \%$ for briquette durability. No major differences in the accuracy of neural models were observed between willow and Miscanthus briquetting. 
Figure 12 shows examples of using ANNs to simulate the briquetting process (this is the most important of the briquette production processes that determines the quality of the final product and energy consumption). The results for one type of sieve (diameter $=15 \mathrm{~mm}$ ) and for two selected humidity levels (10\% and $15 \%)$ are summarized. The comparison of average real values (obtained from measurements) with the values of three output variables calculated by ANNs confirmed the high accuracy of the developed models for the entire range of applied briquetting pressures. It can be observed that in the case of Miscanthus, changes in humidity had a small effect on the values of the output parameters of briquetting (Figure 12d-f). However, for willow, the change in humidity caused significant differences in the case of briquette density and briquette durability (Figure 12b,c). Higher humidity reduced the density and durability of the briquette at the same briquetting pressures. It is worth noting that at $17 \mathrm{MPa}$ pressure, the durability of willow briquettes made from raw material with humidity of $15 \%$ was much lower (by $37 \%$ ) than $10 \%$ biomass briquettes. Despite the large non-linearity of changes, the ANN describing the durability of the briquette simulates the process very well.

A detailed operation algorithm of the DSS inference module is shown in the Figure 13. This diagram can be divided into two parts: the parameters specified by the user and the parameters calculated by the DSS inference module.

The user specifies the type of energy plant (Miscanthus or willow), moisture content of the energy plant and the expected durability of the briquette. If the plant has too much humidity $(>20 \%)$, additional drying of the plant material is necessary.

Based on the given parameters, the DSS inference module calculates the process parameters (settings for the ax chopper, beater mill and piston briquetting press) and determines the forecast parameters of the briquette (durability and specific density). The objective function is to minimize total energy consumption. From the selected durability range and set humidity for the selected plant material, the data set with the lowest total energy consumption was selected. This solution gave the opportunity to perform simulations for many variants of interest to potential users.

The parameters characterizing the quality of produced briquettes are mechanical durability and specific density. These parameters are commonly used as indicators of briquette quality $[8,17,21-23,64]$.

Durability and density are related to each other. For briquettes made of a specific type of biomass and under certain conditions, the higher the density, the greater the durability. The values of these parameters are very important for briquette producers-they affect the costs of transport and storage of briquettes. The higher durability and density of the briquettes means that they have higher transport and load compliance-transport and storage costs are lower. For transport, the limit is the maximum transport volume of the transport means (e.g., trucks), not its load capacity. The higher density of briquettes means that a larger mass can be transported with one transport means. Additionally, higher density briquettes have lower costs of the storage process-a certain mass takes up less storage space, it is better to use storage devices, etc. The greater durability of the briquettes means that they have a higher loadability (stacking resistance), which allows better use of the surface of the transport means and storage space. Briquettes with higher durability are less damaged (crushed) during transport, handling and storage processes.

Examples of user interface screens of the designed DSS are shown in the Figures 16 and 17.

As the DSS is intended for briquette producers in Poland, the user interface is in the Polish language. By asking the DSS question via the user interface (Figure 16), the user enters via the keyboard information: regarding the selected energy plant ("Select Plant"), minimum ("Minimum durability $(\%) ")$ and maximum ("Maximum durability (\%)") durability of the briquette and humidity of the material ("Humidity (\%) Range: 14-20"). After entering the information, the decision-maker can click the calculate button and will be taken to the screen with the DSS response (Figure 17). In case of entering incorrect data, the "Clear" button, which will delete the entered data, may also be clicked. 


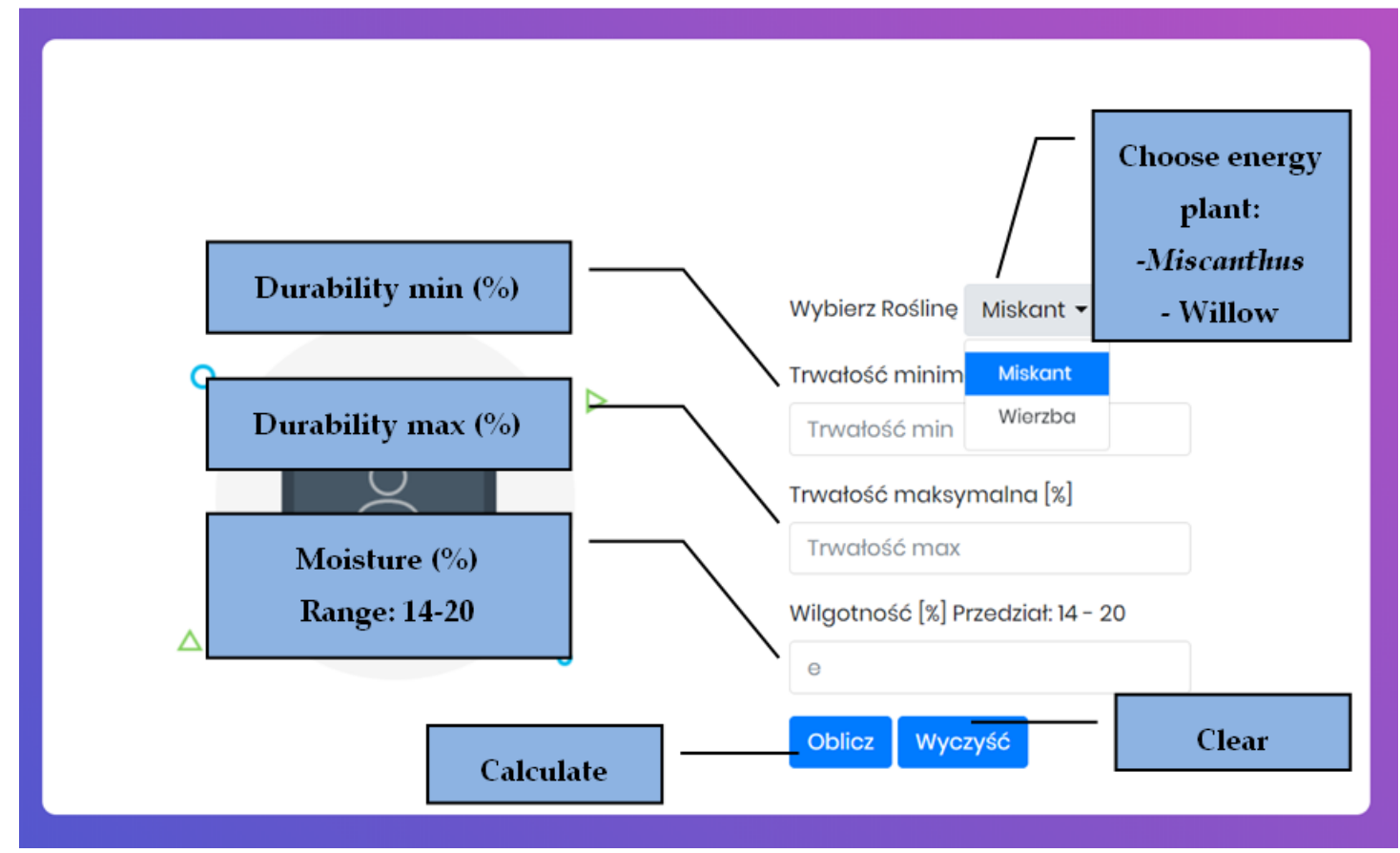

Figure 16. User interface screen of the designed DSS for data entry.

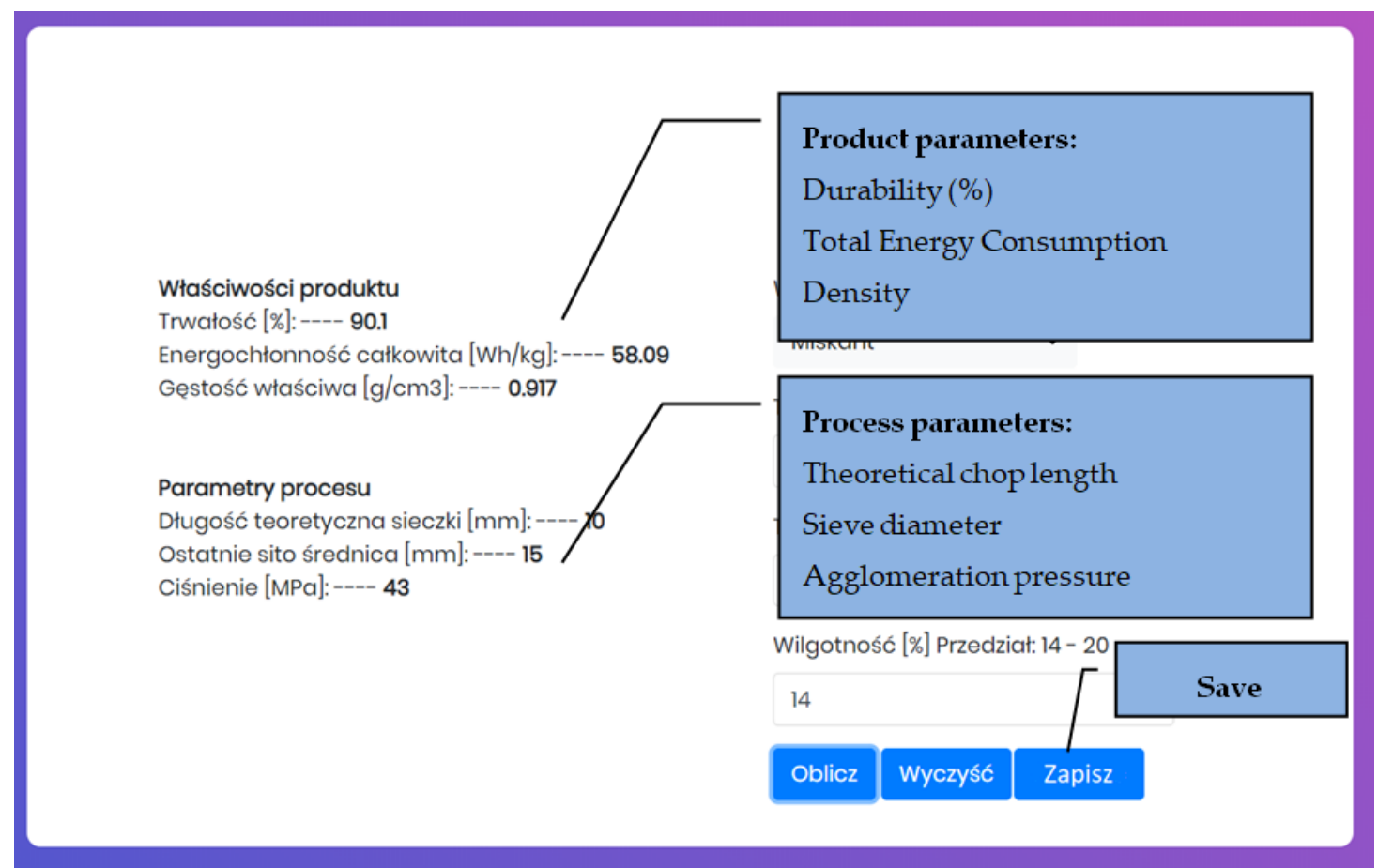

Figure 17. DSS user interface screen with system response.

The screen with the DSS response presents the results of the calculations. The results were divided into two groups: product properties and process parameters. As a part of the process properties, the following are displayed: durability $(\%)$, total energy consumption $(\mathrm{Wh} / \mathrm{kg})$ and specific density $\left(\mathrm{g} / \mathrm{cm}^{3}\right)$. As a part of the process, the following parameters are displayed: theoretical chop length $(\mathrm{mm})$, diameter of the last sieve $(\mathrm{mm})$ and agglomeration pressure $(\mathrm{MPa})$. The decision-maker can save several subsequent unit tests in the form report to compare and choose the best solution. The generated report can be saved and modified. 
The use case diagram (Figure 14) illustrates the main functionality of the system, which consists of the calculating product, input and process parameters, total energy consumption and displaying them. This diagram also shows the division of permissions/tasks between parts of the systems. The user has the authority to enter data and generate, modify and save reports. DSS is designed to interpret input data and perform calculations according to the designed algorithm. The database stores data on input parameters (material properties), ANN models database and forecasted output parameters (product and process).

The implementation diagram (Figure 15) reflects the physical structure of the system. The modules of the web application itself are also distinguished. Due to the use of ready-made libraries (Spring, Hibernate and Spring MVC), the process of analyzing data was significantly shortened.

System operation was confirmed by a series of unit tests. Selected tests are presented in the Tables 4 and 5 . The selected unit tests parameters reflected the upper briquette durability ranges.

Table 4. Simulation results for selected input data-Miscanthus.

\begin{tabular}{cccccccc}
\hline $\begin{array}{c}\text { Durability } \\
\text { Range (\%) }\end{array}$ & $\begin{array}{c}\text { Moisture } \\
(\mathbf{\%})\end{array}$ & $\begin{array}{c}\text { Theoretical } \\
\text { Chop } \\
\text { Length } \\
(\mathbf{m m})\end{array}$ & $\begin{array}{c}\text { Diameter } \\
\text { of the Last } \\
\text { Sieve } \\
\mathbf{( m m )}\end{array}$ & $\begin{array}{c}\text { Briquetting } \\
\text { Pressure } \\
\text { (MPa) }\end{array}$ & $\begin{array}{c}\text { Durability } \\
\mathbf{( \% )}\end{array}$ & $\begin{array}{c}\text { Density } \\
\text { (g/cm } \mathbf{3})\end{array}$ & $\begin{array}{c}\text { Energy } \\
\text { Consumption } \\
\text { (Wh/kg) }\end{array}$ \\
\hline $90-100$ & 14 & 10 & 15 & 43 & 90.1 & 0.917 & 58.09 \\
$80-90$ & 14 & 10 & 15 & 20 & 81.0 & 0.748 & 24.51 \\
$90-100$ & 15 & 10 & 15 & 36 & 90.1 & 0.827 & 53.71 \\
$80-90$ & 15 & 10 & 15 & 20 & 80.9 & 0.748 & 24.28 \\
$90-100$ & 16 & 10 & 15 & 36 & 90.4 & 0.825 & 53.02 \\
$80-90$ & 16 & 10 & 15 & 20 & 80.6 & 0.751 & 24.19 \\
$90-100$ & 17 & 10 & 15 & 39 & 90.2 & 0.857 & 54.41 \\
$80-90$ & 17 & 10 & 15 & 22 & 80.1 & 0.757 & 24.31 \\
$90-100$ & 18 & 10 & 15 & 38 & 90.4 & 0.857 & 53.81 \\
$80-90$ & 18 & 10 & 15 & 22 & 80.2 & 0.747 & 24.3 \\
$90-100$ & 19 & 10 & 15 & 39 & 90.0 & 0.864 & 57.05 \\
$80-90$ & 19 & 10 & 15 & 23 & 80.4 & 0.736 & 24.75 \\
$90-100$ & 20 & 10 & 10 & 33 & 90.0 & 0.796 & 62.18 \\
$80-90$ & 20 & 10 & 15 & 28 & 80.4 & 0.743 & 36.98 \\
\hline
\end{tabular}

Table 5. Simulation results for selected input data-willow.

\begin{tabular}{cccccccc}
\hline $\begin{array}{c}\text { Durability } \\
\text { Range (\%) }\end{array}$ & $\begin{array}{c}\text { Moisture } \\
\mathbf{( \% )}\end{array}$ & $\begin{array}{c}\text { Theoretical } \\
\text { Chop } \\
\text { Length } \\
\mathbf{( m m )}\end{array}$ & $\begin{array}{c}\text { Diameter } \\
\text { of the Last } \\
\text { Sieve } \\
\mathbf{( m m )}\end{array}$ & $\begin{array}{c}\text { Briquetting } \\
\text { Pressure } \\
\text { (MPa) }\end{array}$ & $\begin{array}{c}\text { Durability } \\
\mathbf{( \% )}\end{array}$ & $\begin{array}{c}\text { Density } \\
\text { (g/cm3) }\end{array}$ & $\begin{array}{c}\text { Energy } \\
\text { Consumption } \\
\mathbf{( W h / k g )}\end{array}$ \\
\hline $90-100$ & 14 & 10 & 15 & 42 & 90.0 & 0.859 & 53.83 \\
$80-90$ & 14 & 10 & 15 & 22 & 81.8 & 0.760 & 26.73 \\
$90-100$ & 15 & 10 & 15 & 42 & 90.3 & 0.854 & 53.06 \\
$80-90$ & 15 & 10 & 15 & 20 & 80.3 & 0.709 & 26.06 \\
$90-100$ & 16 & 10 & 15 & 38 & 90.3 & 0.840 & 50.22 \\
$80-90$ & 16 & 10 & 15 & 20 & 91.1 & 0.661 & 26.02 \\
$90-100$ & 17 & 10 & 15 & 44 & 90.2 & 0.832 & 54.12 \\
$80-90$ & 17 & 10 & 15 & 22 & 81.5 & 0.640 & 26.02 \\
$90-100$ & 18 & 10 & 10 & 32 & 90.4 & 0.795 & 73.38 \\
$80-90$ & 18 & 10 & 15 & 26 & 80.9 & 0.631 & 27.08 \\
$90-100$ & 19 & 10 & 10 & 38 & 90.4 & 0.785 & 78.27 \\
$80-90$ & 19 & 10 & 15 & 34 & 80.4 & 0.636 & 51.07 \\
$90-100$ & 20 & 20 & 4 & 36 & 90.6 & 0.853 & 115.24 \\
$80-90$ & 20 & 10 & 10 & 24 & 81.1 & 0.724 & 70.4 \\
\hline
\end{tabular}

The decision maker, having to determine the parameters of the briquette production process, had information about the type of plant (Willow or Miscanthus) and biomass moisture level. He also knew what durability the briquette he wanted to achieve (introduces the minimum and maximum durability 
value to DSS). On this basis the DSS, using ANN models, calculated the parameters of individual stages of the briquette production process (theoretical chop length, diameter of the last sieve and briquetting pressure) and briquette quality parameters (durability and density) with minimal energy consumption.

For example, for Miscanthus with 14\% humidity and the $90 \%-100 \%$ durability range, the DSS process parameters: theoretical chop length $=10 \mathrm{~mm}$, diameter of the last sieve $=15 \mathrm{~mm}$ and briquetting pressure $=43 \mathrm{MPa}$ will ensure briquette durability of $90.1 \%$ with minimal energy consumption of 58.09 $\mathrm{Wh} / \mathrm{kg}$ (Table 4, row 1). If the decision maker states that $80 \%$ durability is sufficient, DSS will calculate new process parameter values (only briquetting pressure $=20 \mathrm{MPa}$ changes) that will ensure briquette durability of $81.0 \%$ with a minimum energy consumption of $24.51 \mathrm{Wh} / \mathrm{kg}$ (Table 4 , row 2 ).

It can be seen that reducing the briquette quality requirements from $90 \%$ to $80 \%$ results in a significant reduction in energy consumption (by about 50\%) for both Miscanthus and willow (Tables 4 and 5).

\section{Conclusions}

The DSS designed and made in this work supported the decision-maker/user in the selection of process parameters for the selected line producing briquettes from energy plants (Miscanthus and willow). The developed DSS is unique-in the literature review no similar decision support tools were found in the processes of producing briquettes from energy plants.

The developed DSS belongs to the class of Intelligent DSSs, as it uses artificial intelligence methods-ANNs. The completed application is fully functional and is ready for implementation in a real production system. Due to the use of web technology, it can be run on a desktop computer, tablet or smartphone. DSS can be used by small enterprises, in which decision-makers usually do not have expertise in the operation of complex computer systems. In Polish conditions, the production of briquettes for energy purposes is most often carried out in small and medium-sized enterprises, therefore there is a demand for this type of DSSs.

The modularity of the system allows future development of the designed system. It is possible to improve the DSS through, e.g., supplementing or improving the model database. The developed DSS is only applicable to the briquetting process. However, due to the open modular structure of the program, after minor program modifications and supplementing the model database with neural networks describing the pellet production process, the DSS can also be used for pellet production. Further research will seek to increase this DSS's functionality. It is planned to supplement it with other types of energy crops and to introduce other types of production lines. In the future, it is planned to add a module for creating production schedules.

Author Contributions: Conceptualization, S.F. and A.K. (Adrian Knapczyk); Methodology, S.F. and A.K. (Adrian Knapczyk); Software, A.K. (Adrian Knapczyk) and A.K. (Artur Knapczyk); Validation, S.F.; Formal analysis, S.F.; Investigation, S.F.; Writing-Original Draft Preparation, S.F., A.K. (Adrian Knapczyk) and R.F.; Writing-Review \& Editing, S.F., A.K. (Adrian Knapczyk) and R.F.; Visualization, A.K. (Adrian Knapczyk). All authors have read and agreed to the published version of the manuscript.

Funding: Article processing charges were financed from the subsidy of the Ministry of Science and Higher Education for the Agricultural University of Hugo Kołłataj in Krakow for the year 2020.

Conflicts of Interest: The authors declare no conflict of interest.

\section{References}

1. Ioannou, K.; Tsantopoulos, G.; Arabatzis, G.; Andreopoulou, Z.; Zafeiriou, E. A Spatial Decision Support System Framework for the Evaluation of Biomass Energy Production Locations: Case Study in the Regional Unit of Drama, Greece. Sustainability 2018, 10, 531. [CrossRef]

2. Brunerová, A.; Roubík, H.; Brožek, M. Bamboo fiber and sugarcane skin as a bio-briquette fuel. Energies 2018, 11, 2186. [CrossRef] 
3. Kozina, T.; Ovcharuk, O.; Trach, I.; Levytska, V.; Ovcharuk, O.; Hutsol, T.; Mudryk, K.; Jewiarz, M.; Wrobel, M.; Dziedzic, K. Spread Mustard and Prospects for Biofuels. In Renewable Energy Sources: Engineering, Technology, Innovation; Mudryk, K., Werle, S., Eds.; Springer Proceedings in Energy; Springer: Berlin/Heidelberg, Germany, 2018; pp. 791-799. ISBN 978-3-319-72371-6.

4. Francik, S.; Knapczyk, A.; Wójcik, A.; Ślipek, Z. Optimisation Methods in Renewable Energy Sources Systems-Current Research Trends. In Renewable Energy Sources: Engineering, Technology, Innovation; Wróbel, M., Jewiarz, M., Szlęk, A., Eds.; Springer: Berlin/Heidelberg, Germany, 2020; pp. 841-852. ISBN 978-3-030-13887-5.

5. Gentil, L.V.; Vale, A.T. Energy balance and efficiency in wood sawdust briquettes production. Floresta 2015, 45, 281-288.

6. Knapczyk, A.; Francik, S.; Wojcik, A.; Bednarz, G. Influence of Storing Miscanthus x gigantheus on Its Mechanical and Energetic Properties. In Renewable Energy Sources: Engineering, Technology, Innovation; Mudryk, K., Werle, S., Eds.; Springer Proceedings in Energy; Springer: Berlin/Heidelberg, Germany, 2018; pp. 651-660.

7. Ivanova, T.; Mendoza Hernández, A.H.; Bradna, J.; Cusimamani, E.F.; Montoya, J.C.G.; Espinel, D.A.A. Assessment of Guava (Psidium guajava L.) wood biomass for briquettes' production. Forests 2018, 9, 613. [CrossRef]

8. Brunerová, A.; Roubík, H.; Brožek, M.; Herák, D.; Šleger, V.; Mazancová, J. Potential of tropical fruit waste biomass for production of bio-briquette fuel: Using Indonesia as an example. Energies 2017, 10, 2119. [CrossRef]

9. Adzic, M.M.; Savic, R.A. Cooling of wood briquettes. Therm. Sci. 2013, 17, 833-838. [CrossRef]

10. Chaloupková, V.; Ivanova, T.; Ekrt, O.; Kabutey, A.; Herák, D. Determination of particle size and distribution through image-based macroscopic analysis of the structure of biomass briquettes. Energies 2018, 11, 331. [CrossRef]

11. Moiceanu, G.; Paraschiv, G.; Voicu, G.; Dinca, M.; Negoita, O.; Chitoiu, M.; Tudor, P. Energy consumption at size reduction of lignocellulose biomass for bioenergy. Sustainability 2019, 11, 2477. [CrossRef]

12. Knapczyk, A.; Francik, S.; Fraczek, J.; Slipek, Z. Analysis of research trends in production of solid biofuels. In Proceedings of the Engineering for Rural Development, Jelgava, Latvia, 22-24 May 2019; Volume 18, pp. 1503-1509.

13. Hebda, T.; Brzychczyk, B.; Francik, S.; Pedryc, N. Evaluation of suitability of hazelnut shell energy for production of biofuels. Eng. Rural Dev. 2018, 17, 1860-1865.

14. Mudryk, K.; Wrobel, M.; Jewiarz, M.; Pelczar, G.; Dyjakon, A. Innovative Production Technology of High Quality Pellets for Power Plants. In Renewable Energy Sources: Engineering, Technology, Innovation; Mudryk, K., Werle, S., Eds.; Springer Proceedings in Energy; Springer: Berlin/Heidelberg, Germany, 2018; pp. 701-712. ISBN 978-3-319-72371-6; 978-3-319-72370-9.

15. Francik, S.; Knapczyk, A.; Francik, R.; Slipek, Z. Analysis of Possible Application of Olive Pomace as Biomass Source. In Renewable Energy Sources: Engineering, Technology, Innovation; Mudryk, K., Werle, S., Eds.; Springer Proceedings in Energy; Springer: Berlin/Heidelberg, Germany, 2018; pp. 583-592.

16. Ivanyshyn, V.; Nedilska, U.; Khomina, V.; Klymyshena, R.; Hryhoriev, V.; Ovcharuk, O.; Hutsol, T.; Mudryk, K.; Jewiarz, M.; Wrobel, M.; et al. Prospects of Growing Miscanthus as Alternative Source of Biofuel. In Renewable Energy Sources: Engineering, Technology, Innovation; Mudryk, K., Werle, S., Eds.; Springer Proceedings in Energy; Springer: Berlin/Heidelberg, Germany, 2018; pp. 801-812.

17. Wrobel, M.; Mudryk, K.; Jewiarz, M.; Glowacki, S.; Tulej, W. Characterization of Selected Plant Species in Terms of Energetic Use. In Renewable Energy Sources: Engineering, Technology, Innovation; Mudryk, K., Werle, S., Eds.; Springer Proceedings in Energy; Springer: Berlin/Heidelberg, Germany, 2018; pp. 671-681.

18. Xu, J.; Chang, S.; Yuan, Z.; Jiang, Y.; Liu, S.; Li, W.; Ma, L. Regionalized techno-economic assessment and policy analysis for biomass molded fuel in China. Energies 2015, 8, 13846-13863. [CrossRef]

19. Wróbel, M. Assessment of Agglomeration Properties of Biomass-Preliminary Study. In Renewable Energy Sources: Engineering, Technology, Innovation; Wróbel, M., Jewiarz, M., Szlęk, A., Eds.; Springer: Berlin/Heidelberg, Germany, 2020; pp. 411-418. ISBN 978-3-030-13887-5.

20. Francik, S.; Łapczyńska-Kordon, B.; Francik, R.; Wójcik, A. Modeling and Simulation of Biomass Drying Using Artificial Neural Networks. In Renewable Energy Sources: Engineering, Technology, Innovation.; Mudryk, K., Werle, S., Eds.; Springer International Publishing AG; Springer: Berlin/Heidelberg, Germany, 2018; pp. 571-581. ISBN 9783319723716. 
21. Wrobel, M.; Mudryk, K.; Jewiarz, M.; Knapczyk, A. Impact of raw material properties and agglomeration pressure on selected parmeters of granulates obtained from willow and black locust biomass. Eng. Rural Dev. 2018, 17, 1933-1938.

22. Safana, A.A.; Abdullah, N.; Sulaiman, F. Bio-char and bio-oil mixture derived from the pyrolysis of mesocarp fibre for briquettes production. J. Oil Palm Res. 2018, 30, 130-140.

23. Brunerová, A.; Brožek, M.; Šleger, V.; Nováková, A. Energy Balance of Briquette Production from Various Waste Biomass. Sci. Agric. Bohem. 2018, 49, 236-243. [CrossRef]

24. Krizan, P.; Matus, M.; Soos, L.; Beniak, J. Behavior of Beech Sawdust during Densification into a Solid Biofuel. Energies 2015, 8, 6382-6398. [CrossRef]

25. Brand, M.A.; Balduino Junior, A.L.; Nones, D.L.; Gaa, A.Z.N. Potential of bamboo species for the production of briquettes [Potencial de espécies de bambu para a produção de briquetes]. Pesqui. Agropecu. Trop. 2019, 49, 236-243. [CrossRef]

26. Islam, S.; Ahiduzzaman, M. Assessment of Rice Husk Briquette Fuel Use as an Alternative Source of Woodfuel. Int. J. Renew. Energy Res. 2016, 6, 1601-1611.

27. Mazurkiewicz, J.; Marczuk, A.; Pochwatka, P.; Kujawa, S. Maize Straw as a Valuable Energetic Material for Biogas Plant Feeding. Materials 2019, 12, 3848. [CrossRef]

28. Felsberger, A.; Oberegger, B.; Reiner, G. A review of decision support systems for manufacturing systems. In Proceedings of the CEUR Workshop Proceedings, Graz, Austria, 18-19 October 2016; Volume 1793.

29. Knapczyk, A.; Francik, S.; Wróbel, M.; Jewiarz, M.; Mudryk, K. Decision support systems for scheduling tasks in biosystems engineering. In Proceedings of the E3S Web of Conferences, Czajowice, Poland, 19-20 September 2019; Volume 132.

30. Hasan, M.S.; Ebrahim, Z.; Wan Mahmood, W.H.; Ab Rahman, M.N. Decision support system classification and its application in manufacturing sector: A review. J. Teknol. 2017, 79, 153-163. [CrossRef]

31. Behmel, S.; Damour, M.; Ludwig, R.; Rodriguez, M. Optimization of river and lake monitoring programs using a participative approach and an intelligent decision-support system. Appl. Sci. 2019, 9, 4157. [CrossRef]

32. Han, H.; Huang, M.; Zhang, Y.; Liu, J. Decision support system for medical diagnosis utilizing imbalanced clinical data. Appl. Sci. 2018, 8, 1597. [CrossRef]

33. Teniwut, W.A.; Hasyim, C.L. Decision support system in supply chain: A systematic literature review. Uncertain Supply Chain Manag. 2020, 8, 131-148. [CrossRef]

34. Kaklauskas, A.; Dzemyda, G.; Tupenaite, L.; Voitau, I.; Kurasova, O.; Naimaviciene, J.; Rassokha, Y.; Kanapeckiene, L. Artificial Neural Network-Based Decision Support System for Development of an Energy-Efficient Built Environment. Energies 2018, 11, 1994. [CrossRef]

35. Badami, M.; Fambri, G.; Manco, S.; Martino, M.; Damousis, I.G.; Agtzidis, D.; Tzovaras, D. A Decision Support System Tool to Manage the Flexibility in Renewable Energy-Based Power Systems. Energies 2020, 13, 153. [CrossRef]

36. Besser, A.; Kazak, J.K.; Świąder, M.; Szewrański, S. A Customized Decision Support System for Renewable Energy Application by Housing Association. Sustainability 2019, 11, 4377. [CrossRef]

37. Stamatescu, I.; Arghira, N.; Fagarasan, I.; Stamatescu, G.; Iliescu, S.S.; Calofir, V. Decision Support System for a Low Voltage. Energies 2017, 10, 118. [CrossRef]

38. Aran Carrion, J.; Espin Estrella, A.; Aznar Dols, F.; Zamorano Toro, M.; Rodriguez, M.; Ramos Ridao, A. Environmental decision-support systems for evaluating the carrying capacity of land areas: Optimal site selection for grid-connected photovoltaic power plants. Renew. Sustain. Energy Rev. 2008, 12, 2358-2380. [CrossRef]

39. Martín-Gamboa, M.; Dias, L.C.; Quinteiro, P.; Freire, F.; Arroja, L.; Dias, A.C. Multi-Criteria and Life Cycle Assessment of Wood-Based Bioenergy Alternatives for Residential Heating: A Sustainability Analysis. Energies 2019, 12, 4391. [CrossRef]

40. Tamouridou, A.A.; Pantazi, E.X.; Alexandridis, T.; Lagopodi, A.; Kontouris, G.; Moshou, D. Spectral Identification of Disease in Weeds Using Multilayer Perceptron with Automatic Relevance Determination. Sensors 2018, 18, 2770. [CrossRef]

41. Sampaio, G.S.; de Aguiar Vallim Filho, A.R.; da Silva, L.S.; da Silva, L.A. Prediction of Motor Failure Time Using An Artificial Neural Network. Sensors 2019, 19, 4342. [CrossRef]

42. Runge, J.; Zmeureanu, R. Forecasting Energy Use in Buildings Using Artificial Neural Networks: A Review. Energies 2019, 12, 3254. [CrossRef] 
43. Kasantikul, K.; Yang, D.; Wang, Q.; Lwin, A. A Novel Wind Speed Estimation Based on the Integration of an Artificial Neural Network and a Particle Filter Using BeiDou GEO Reflectometry. Sensors 2018, 18, 3350. [CrossRef] [PubMed]

44. Francik, S.; Kurpaska, S. The Use of Artificial Neural Networks for Forecasting of Air Temperature inside a Heated Foil Tunnel. Sensors 2020, 20, 652. [CrossRef] [PubMed]

45. Liu, Y.; Zhang, S.; Chen, X.; Wang, J. Artificial Combined Model Based on Hybrid Nonlinear Neural Network Models and Statistics Linear Models-Research and Application for Wind Speed Forecasting. Sustainability 2018, 10, 4601. [CrossRef]

46. Niedbała, G.; Nowakowski, K.; Rudowicz-Nawrocka, J.; Magdalena, P.; Tomczak, R.J.; Tyksiński, T.; Pinto, A.A. Multicriteria Prediction and Simulation of Winter Wheat Yield Using Extended Qualitative and Quantitative Data Based on Artificial Neural Networks. Appl. Sci. 2019, 9, 2773. [CrossRef]

47. Mudryk, K.; Francik, S.; Fraczek, J.; Slipek, Z.; Wrobel, M. Model of actual contact area of rye and wheat grains with flat surface. In Proceedings of the Engineering for Rural Development, Jelgava, Latvia, 23-24 May 2013; pp. 292-296.

48. Wrobel, M.; Fraczek, J.; Francik, S.; Slipek, Z.; Mudryk, K. Modelling of unit contact surface of bean seeds using Artificial Neural Networks. In Proceedings of the Engineering for Rural Development, Jelgava, Latvia, 23-24 May 2013; pp. 287-291.

49. Francik, S.; Ślipek, Z.; Frączek, J.; Knapczyk, A. Present Trends in Research on Application of Artificial Neural Networks in Agricultural Engineering. Agric. Eng. 2016, 20, 15-25. [CrossRef]

50. Vlontzos, G.; Pardalos, P.M. Assess and prognosticate green house gas emissions from agricultural production of EU countries, by implementing, DEA Window analysis and artificial neural networks. Renew. Sustain. Energy Rev. 2017, 76, 155-162. [CrossRef]

51. Liakos, K.G.; Busato, P.; Moshou, D.; Pearson, S.; Bochtis, D.D. Machine Learning in Agriculture: A Review. Sensors 2018, 18, 2674. [CrossRef]

52. Iddio, E.; Wang, L.; Thomas, Y.; McMorrow, G.; Denzer, A. Energy efficient operation and modeling for greenhouses: A literature review. Renew. Sustain. Energy Rev. 2020, 117, 109480. [CrossRef]

53. Almonti, D.; Baiocco, G.; Tagliaferri, V.; Ucciardello, N. Artificial Neural Network in Fibres Length Prediction for High Precision Control of Cellulose Refining. Materials 2019, 12, 3730. [CrossRef]

54. Tamouridou, A.A.; Alexandridis, T.K.; Pantazi, X.E.; Lagopodi, A.L.; Kashefi, J.; Kasampalis, D.; Kontouris, G.; Moshou, D. Application of Multilayer Perceptron with Automatic Relevance Determination on Weed Mapping Using. Sensors 2017, 17, 2307. [CrossRef]

55. Martinez-Martinez, V.; Baladron, C.; Gomez-Gil, J.; Ruiz-Ruiz, G.; Navas-Garcia, L.M.; Aguiar, J.M.; Carro, B. Temperature and Relative Humidity Estimation and Prediction in the Tobacco Drying Process Using Artificial Neural Networks. Sensors 2012, 12, 14004-14021. [CrossRef] [PubMed]

56. Niedbała, G. Application of Artificial Neural Networks for Multi-Criteria Yield Prediction of Winter Rapeseed. Sustainability 2019, 11, 533. [CrossRef]

57. Bermejo, J.F.; Fernandez, J.F.G.; Polo, F.O.; Marquez, A.C. A Review of the Use of Artificial Neural Network Models for Energy and Reliability Prediction. A Study of the Solar PV, Hydraulic and Wind Energy Sources. Appl. Sci. 2019, 9, 1844. [CrossRef]

58. Tina, G.M. Special Issue on Applications of Artificial Neural Networks for Energy Systems. Appl. Sci. 2019, 9, 3734. [CrossRef]

59. Zhou, J.; Xu, X.; Huo, X.; Li, Y. Forecasting Models for Wind Power Using Extreme-Point Symmetric Mode Decomposition and Artificial Neural Networks. Sustainability 2019, 11, 650. [CrossRef]

60. Yu, H.; Chen, Y.; Hassan, S.G.; Li, D. Prediction of the temperature in a Chinese solar greenhouse based on LSSVM optimized by improved PSO. Comput. Electron. Agric. 2016, 122, 94-102. [CrossRef]

61. Rodrigues, E.; Gomes, Á.; Gaspar, A.R.; Henggeler Antunes, C. Estimation of renewable energy and built environment-related variables using neural networks-A review. Renew. Sustain. Energy Rev. 2018, 94, 959-988. [CrossRef]

62. Reynolds, J.; Ahmad, M.W.; Rezgui, Y.; Hippolyte, J.L. Operational supply and demand optimisation of a multi-vector district energy system using artificial neural networks and a genetic algorithm. Appl. Energy 2019, 235, 699-713. [CrossRef]

63. Zheng, M.; Leib, B.; Wright, W.; Ayers, P. Neural models to predict temperature and natural ventilation in a high tunnel. Trans. ASABE 2019, 62, 761-769. [CrossRef] 
64. Wrobel, M.; Fraczek, J.; Francik, S.; Slipek, Z.; Mudryk, K. Influence of degree of fragmentation on chosen quality parameters of briquette made from biomass of cup plant Silphium perfoliatum L. In Proceedings of the Engineering for Rural Development, Jelgava, Latvia, 23-24 May 2013; pp. 653-657.

65. Byliński, H.; Sobecki, A.; Gebicki, J. The Use of Artificial Neural Networks and Decision Trees to Predict the Degree of Odor Nuisance of Post-Digestion Sludge in the Sewage Treatment Plant Process. Sustainability 2019, 11, 4407. [CrossRef] 